

\title{
Reproductive biology of Australian acacias: important mediator of invasiveness?
}

Michelle R. Gibson ${ }^{1 \star}$, David M. Richardson ${ }^{1}$, Elizabete Marchante ${ }^{2}$, Hélia Marchante ${ }^{2,3}$, James G. Rodger ${ }^{4}$, Graham N. Stone ${ }^{5}$, Margaret Byrne ${ }^{6}$, Andrés Fuentes-Ramírez ${ }^{7,8}$, Nicholas George ${ }^{9}$, Carla Harris ${ }^{10}$, Steven D. Johnson ${ }^{4}$, Johannes J. Le Roux ${ }^{1}$, Joseph T. Miller ${ }^{11}$, Daniel J. Murphy ${ }^{12}$, Anton Pauw ${ }^{13}$, Matthew N. Prescott ${ }^{14}$, Elizabeth M. Wandrag ${ }^{15}$ and John R. U. Wilson ${ }^{1,16}$

${ }^{1}$ Centre for Invasion Biology, Department of Botany and Zoology, Stellenbosch University, Matieland 7602, South Africa, ${ }^{2}$ Department of Life Sciences, Centre for Functional Ecology, University of Coimbra, Apartado 3046, Coimbra 3001-401, Portugal, ${ }^{3}$ Centre for Studies of Natural Resources, Environment and Society; Department of Environment, Escola Superior Agrária de Coimbra, Bencanta, Coimbra 3040-316, Portugal, ${ }^{4}$ Centre for Invasion Biology, School of Biological and Conservation Sciences, University of KwaZulu-Natal, P. Bag X01 Scottsville, Pietermaritzburg 3209, South Africa, ${ }^{5}$ Institute of Evolutionary Biology, University of Edinburgh, The King's Buildings, West Mains Road, Edinburgh EH9 3JT, UK, ${ }^{6}$ Science Division, Department of Environment and Conservation, Locked Bag 104 Bentley Delivery Centre, Bentley, WA 6983, Australia, ${ }^{7}$ Laboratorio de Invasiones Biológicas (LIB), Facultad de Ciencias Forestales, Universidad de Concepción, Casilla 160-C, Concepción, Chile, ${ }^{8}$ Instituto de Ecología y Biodiversidad (IEB), Santiago, Chile, ${ }^{9}$ School of Plant Biology, Faculty of Natural and Agricultural Sciences, The University of Western Australia, 35 Stirling Highway, Crawley, WA 6009, Australia, ${ }^{10}$ Plant Invasion and Restoration Ecology Laboratory, Department of Biological Sciences, Faculty of Science, Macquarie University, Sydney, NSW 2109, Australia, ${ }^{11}$ Centre for Australian National Biodiversity Research, GPO Box 1600, CSIRO Plant Industry, Canberra, ACT 2601, Australia, ${ }^{12}$ National Herbarium of Victoria, Royal Botanic Gardens Melbourne, Private Bag 2000, Birdwood Avenue, South Yarra, Vic. 3141, Australia, ${ }^{13}$ Department of Botany and Zoology, Stellenbosch University, Matieland 7602, South Africa, ${ }^{14}$ Department of Zoology, Oxford University, South Parks Road, Oxford OX1 3PS, UK, ${ }^{15}$ Bio-Protection Research Centre, Lincoln University, Canterbury 7647, New Zealand, ${ }^{16}$ South African National Biodiversity Institute, Kirstenbosch National Botanical Gardens, Claremont 7735, South Africa

${ }^{*}$ Correspondence: Michelle R. Gibson, Centre for Invasion Biology, Department of Botany \& Zoology, Stellenbosch University, Matieland 7602, South Africa. E-mail: mishka.r.g@gmail.com

\section{ABSTRACT}

Aim Reproductive traits are important mediators of establishment and spread of introduced species, both directly and through interactions with other life-history traits and extrinsic factors. We identify features of the reproductive biology of Australian acacias associated with invasiveness.

\section{Location Global.}

Methods We reviewed the pollination biology, seed biology and alternative modes of reproduction of Australian acacias using primary literature, online searches and unpublished data. We used comparative analyses incorporating an Acacia phylogeny to test for associations between invasiveness and eight reproductive traits in a group of introduced and invasive (23) and non-invasive (129) species. We also explore the distribution of groups of trait 'syndromes' between invasive and non-invasive species.

Results Reproductive trait data were only available for 126 of 152 introduced species in our data set, representing 23/23 invasive and 103/129 non-invasive species. These data suggest that invasives reach reproductive maturity earlier (10/ 13 within 2 years vs. 7/26 for non-invasives) and are more commonly able to resprout (11/21 vs. 13/54), although only time to reproductive maturity was significant when phylogenetic relationships were controlled for. Our qualitative survey of the literature suggests that invasive species in general tend to have generalist pollination systems, prolific seed production, efficient seed dispersal and the accumulation of large and persistent seed banks that often have fire-, heat- or disturbance-triggered germination cues.

Conclusions Invasive species respond quicker to disturbance than non-invasive taxa. Traits found to be significant in our study require more in-depth analysis involving data for a broader array of species given how little is known of the reproductive biology of so many taxa in this species-rich genus. Sets of reproductive traits characteristic of invasive species and a general ability to reproduce effectively in new locations are widespread in Australian acacias. Unless there is substantial evidence to the contrary, care should be taken with all introductions.

\section{Keywords}

Biological invasions, breeding system, invasive alien species, pollination, reproductive syndromes, reproductive traits, seed dispersal 


\section{INTRODUCTION}

A predictive understanding of invasiveness is needed to manage existing invasive species and for objective screening of new introductions. Elucidating the determinants of invasiveness and understanding how these interact with environmental features and extrinsic factors to mediate invasion success are fundamental questions in invasion ecology (Richardson \& Pyšek, 2006). Anthropogenic and environmental factors and various life-history traits, particularly features associated with reproduction and dispersal (Rejmánek et al., 2005; Thuiller et al., 2006; Pyšek \& Richardson, 2007), are often associated with invasion success (or lack thereof). Previous studies comparing life-history traits of invasive species have found several reproductive traits including seed mass, fecundity (number of seeds produced), dispersal mode and dispersal ability to be important for overcoming barriers to invasion in a new environment (Hamilton et al., 2005; Pyšek \& Richardson, 2007; Moravcová et al., 2010; Castro-Díez et al., 2011). There has, however, been no comprehensive analysis of the roles of such traits in invasiveness in Australian acacias, a speciose group of plants containing several invasive species.

This study assesses the current state of knowledge regarding associations between reproductive traits and invasiveness in this group, which here refers to the $c a .1012$ taxa in the genus Acacia (hereafter referred to as 'Australian acacias' or Acacia, formerly placed in Acacia subgenus Phyllodineae and synonymous with Racosperma) that have Australia as at least part of their native range; see Miller et al. (2011) for a more recent phylogenetic treatment of this and related groups. To do this, we present an analysis in two parts: (1) a quantitative comparative analysis of specific reproductive traits for which appropriate data were available; and (2) a qualitative literature review of reproductive traits for which we could not find quantitative data, but which may be important in predicting invasiveness. We conclude with the implications for management.

Australian acacias are an excellent group for exploring determinants of invasiveness and are likely to become a model system against which other invasive plant groups are compared (Richardson et al., 2011). They comprise a phylogenetically and geographically distinct group (natural distributions virtually confined to the Australian continental landmass) with 1012 described species (Richardson et al., 2011), of which at least a third have been introduced and 23 are invasive in different parts of the world (Richardson \& Rejmánek, 2011; Richardson et al., 2011). Their well-documented introduction histories (e.g. Le Roux et al., 2011) and records of invasiveness in different introduced ranges make comparative studies possible on continental and global scales. Australian acacias appear to possess a suite of reproductive and other life-history traits that have been suggested as instrumental in their success as invasive species (Milton \& Hall, 1981; Richardson \& Kluge, 2008). Unfortunately, invasive taxa among Australian acacias are far better studied than are non-invasive taxa; this is in line with a general bias in invasion ecology whereby invasive species that exert greater impacts on invaded environment are better studied (Pyšek et al., 2008). This complicates statistical analysis of associations between species character traits and invasiveness.

Little is known in general about such associations (Gallagher et al., 2011), and to date, no multi-species, multi-regional study has explored how reproductive traits influence invasiveness of Australian acacias. In this study, we review available published and unpublished information on their reproductive traits and trait 'syndromes' (sets of reproductive traits that repeatedly favour a particular group of pollinators, method of reproduction, agent of seed dispersal or germination system) and compare trait values between (1) rare and common Australian acacias; (2) invasive Australian species in their native and introduced ranges; and (3) introduced invasive species and introduced non-invasive Australian acacias. Our aim is to identify those traits associated with invasiveness. Our approach has been dictated by the availability of data. For those traits for which data are available (Table S1), we use phylogenetically controlled comparative analyses to ask which reproductive traits, alone or in combination, are significant correlates of invasiveness. For those traits we were unable to analyse quantitatively, we qualitatively review all available information to address the questions: (1) Are there distinct reproductive syndromes that differ between invasive and noninvasive species? and (2) does pollinator-mediated seed production reduce or enhance naturalization or invasion in any regions? Such an approach has the potential to yield insights that are of value to plant invasion ecology in general and for refining screening protocols (e.g. Gordon et al., 2010) for assessing the risk of further introductions of Acacia species that may lead to invasions.

\section{Methods}

Species list

We used the classification scheme of Richardson \& Rejmánek (2011) to define which species are considered invasive $(\mathrm{n}=23$ ). The objective criteria used in their study (following Pyšek et al., 2004) are more conservative than those applied by others (e.g. Randall, 2002), and only species that have spread considerable distances from parent populations are considered 'invasive'. However, the criteria are not as strict as in other studies, such as Castro-Díez et al. (2011), who regarded species as 'invasive' (sensu Pyšek et al., 2004) only when supported by at least two different sources of information from different countries. Species were defined as having been introduced ( $\mathrm{n}=152$ ) only if a herbarium record for that species has been collected from outside Australia (Richardson et al., 2011).

We compiled data on at least one of eight reproductive traits for 450 of the 1012 species in the Australian Acacia group. Of the 860 non-introduced species, data were available for six of the traits for 324 species (Table S2). Of the 152 introduced species, data were available for all eight traits for 126 species 


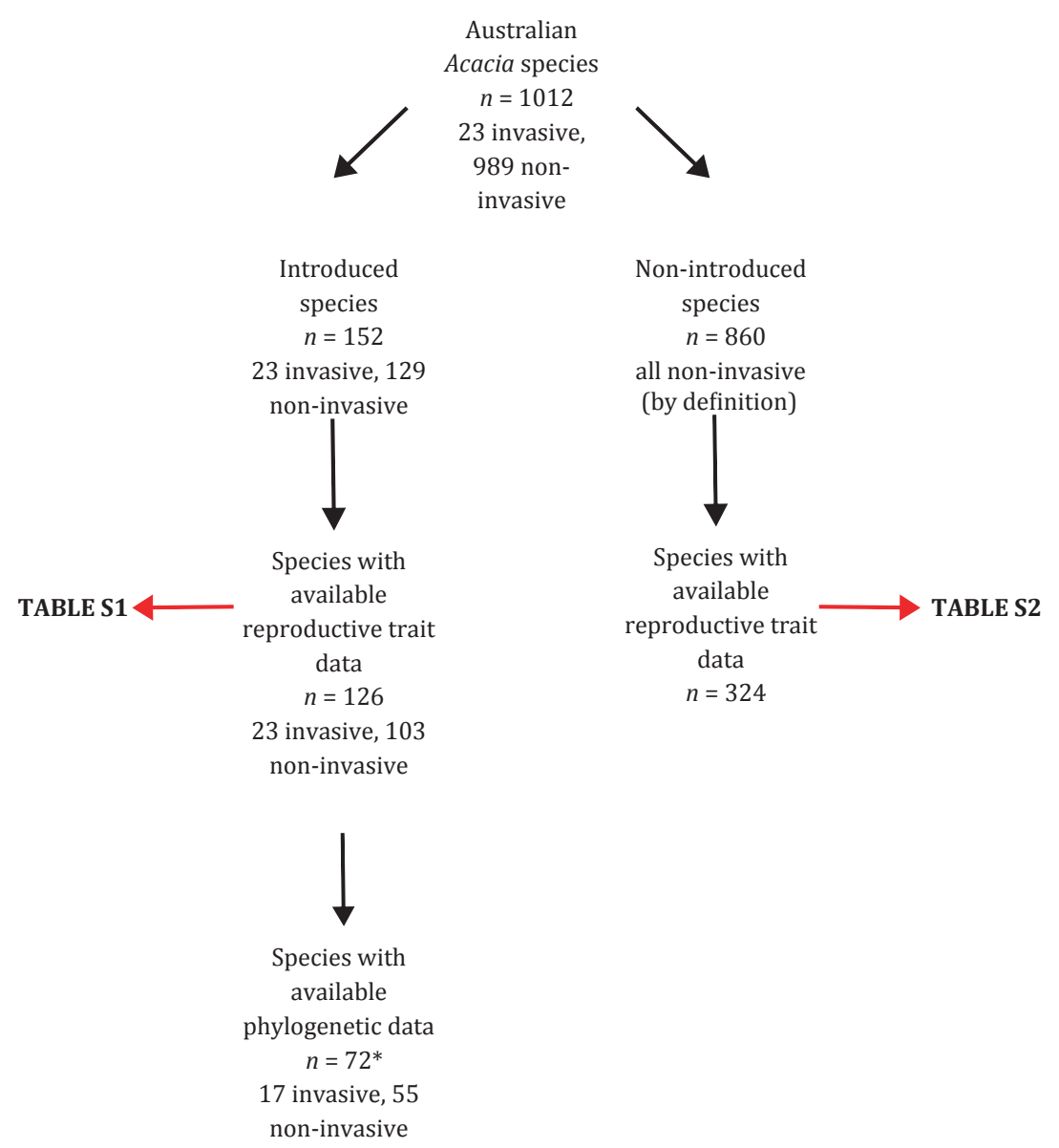

Figure 1 Breakdown of Australian Acacia species used in this study. ${ }^{\star}$ One of the species for which there was phylogenetic data had no available reproductive trait data.

(23 invasive, 103 non-invasive; see Table S1) - see Fig. 1 for a breakdown of species used in this study. We analysed data on reproductive traits using only introduced species to reduce biases caused during the introduction process.

\section{Statistical analysis}

We used $\mathrm{R}$ for all statistical analyses ( $\mathrm{R}$ Development Core Team, 2011). Reproductive traits were used as explanatory variables, and invasive status (invasive and non-invasive) was used as the response variable. Explanatory variables used in quantitative analyses comprised: time to reproductive maturity; index of self-incompatibility (ISI) (number of infructescences/inflorescence); ISI (number of pods/inflorescence); combined measure of breeding system; dispersal agent (antor bird-dispersed seed); seed mass; resprouting ability; and length of flowering period (see Appendix 1 for details and references). Seed mass was log transformed to reduce skewness in the data. Seeds were considered to be dispersed by birds either if this was conclusively reported in the literature or, based on seed morphological traits, if the arils/funicles or elaiosomes were specifically described as being orange, yellow or red. Species were considered to be 'not bird dispersed' if they were reported to be dispersed by ants in the literature and where dispersal by birds was not mentioned. Species for which clear data were not available were omitted from the analysis. A combined measure of breeding system was inferred from multi-locus outcrossing rate $\left(t_{\mathrm{m}}\right)$, both ISI measurements, and breeding system $\left(t_{\mathrm{m}}\right.$ and breeding system not used in final analyses; see Appendix 1 and Table S1). We considered a species as outcrossing if $t_{\mathrm{m}} \geq 0.8$ or ISI $\leq 0.5$; otherwise, species were considered to have mixed mating systems.

Because species do not represent independent data points in comparative studies (Hadfield \& Nakagawa, 2010; Stone et al., 2011), we incorporated phylogenetic relationships among sampled species into our analyses using a generalized leastsquares (gls) framework in the nlme package (Pinheiro et al., 2009). This approach assumes a Brownian model of character evolution in which trait covariance between a pair of species decreases linearly since their time of divergence from a shared common ancestor. The phylogenetic relationship between taxa was inferred using Bayesian methods incorporated in the software MrBayes version 3.1.2 (Ronquist \& Huelsenbeck, 2003). Our analysis incorporates sequence data for two nuclear genes (nuclear ribosomal DNA internal (ITS) and external (ETS) transcribed spacers) and four chloroplast regions ( $p s b \mathrm{~A}-$ trn $\mathrm{H}$ intergenic spacer, trnL-F intron and intergenic spacer, rpl32-trnL intergenic spacer and a portion of the matK 
introns), comprising a tandem alignment of 5912 base pairs. Contiguous sequences were edited using Sequencher ${ }^{\mathrm{TM}}$ v.3.0 (Gene Codes Corporation) and manually aligned in BioEdit sequence alignment editor v.4.8.6 (Hall, 1999). Appropriate models of molecular evolution for implementation in MrBayes were identified using the programme Modeltest v.1.1 (Posada \& Crandall, 1998), which identified the GTR + I + G model (general time reversible model incorporating a proportion of invariant sites and gamma-distributed rate variation in variable sites) for both the plastid and nuclear partitions of our data set. The Markov chain Monte Carlo search in MrBayes was run for two million generations with trees sampled every 1000 generations. MrBayes performed two simultaneous analyses starting from different random trees (Nruns =2), each with four Markov chains (Nchains = 4). The first 200 sampled trees were discarded from each run as burn-in. We used the $50 \%$ majority rule consensus phylogram as our working phylogeny, with node support expressed in terms of posterior probability values. All trees were rooted using Pararchidendron pruinosum as an outgroup taxon.

The resultant phylogeny incorporated 72 species of the 126 species (see Miller et al., 2011), and only data for these species were incorporated into phylogenetically controlled analyses (17 invasive, 55 non-invasive; see Fig. 2 for phylogenetic tree and Appendix S1 for species accession numbers). Because our analytical approach to determine phylogenetic independence requires a fully resolved phylogeny, polytomies were broken by inserting very small non-zero branch lengths. Reanalysis with such instances pruned from the data gave near-identical results (not shown). To assess the impact of phylogenetic patterns in our trait data, we compared analyses incorporating phylogenetic information for this subset of 72 species with phylogenyfree analyses for the same species set. To illustrate patterns in the full data set, we also carried out phylogeny-free analyses across the full set of 126 species. For both data sets $(n=72$ and $n=126$ ), phylogeny-free tests of trait differences between invasive and non-invasive species involved Pearson's chisquare tests for binary explanatory variables and generalized linear models for individual continuous explanatory variables.

\section{Results}

Of the eight reproductive traits we assessed, only two showed significant differences between invasive and non-invasive species in phylogeny-free analyses (Table 1A,B; see Appendix S2 for actual parameter estimates, results were similar when using either all 126 species or the subset of 72 species for which we have a phylogeny). The proportion of species that reach reproductive maturity within two years was significantly higher for invasive acacias $\left(\chi^{2}=6.90\right.$, d.f. $\left.=1, P=0.009\right)$. Invasive species also had a significantly higher probability of being resprouters $\left(\chi^{2}=4.34\right.$, d.f. $\left.=1, P=0.037\right)$ than non-invasive species. Incorporation of phylogenetic relationships into the analysis for 72 species removed the significance of resprout ability, but supported our results from the phylogeny-free analyses that invasive species reach reproductive maturity earlier (gls: coefficient $=-0.553, t=-3.18, P=0.004 ;$ Table 1B, Appendix S3).

\section{LITERATURE REVIEW: REPRODUCTIVE BIOLOGY OF AUSTRALIAN ACACIAS}

\section{Pollination biology}

As a broad generalization, we expect successful invasive species to share at least some of the following floral traits (Baker, 1955; Chittka \& Schürkens, 2001; Brown et al., 2002; Ghazoul, 2002; Gross et al., 2010):

1. High attractiveness to available flower visitors and floral morphologies allowing pollination by many different organisms.

2. Production of very large numbers of long-lived flowers allowing seed-set even when visitation rates are low; and/or an ability to self-pollinate or reproduce vegetatively.

3. Floral induction cues match those triggering flowering in native species and emergence of native flower visitors.

Worldwide, taxa classified in the polyphyletic group Acacia sensu lato (genera Acaciella, Mariosousa, Senegalia, Vachellia; McNeill et al., 2006) share many of these morphological traits but differ in their global distributions, pollinator assemblages and specific aspects of floral biology (Stone et al., 2003). All have small tubular flowers collected together into spherical or elongated flower heads, with pollen presented on the inflorescence surface (Stone et al., 2003; Raine et al., 2007). Clustering of the pollen grains into a composite unit, termed a 'polyad', is a key component of the pollination efficiency of all acacias, providing an efficient means of dispersal via pollinators (Kenrick \& Knox, 1982). There are always fewer ovules per ovary than pollen grains per polyad, so one polyad from a single pollination event can potentially fertilize all the ovules (Kenrick \& Knox, 1982). The stigmas of the flowers are also distributed over the surface of the flower heads and are freely accessible, so that any insect that travels from one tree to another is a potential pollinator. Recruitment of insects is often enhanced by the release of floral scent just before pollen release, and visual advertisement is often maximized by synchronized opening of flowers, both within a single tree and often within a local species' population (Stone et al., 2003). Floral morphology is a conserved trait across the genus and does not distinguish invasive from non-invasive Australian acacias. Such generalized morphology may facilitate invasion as it reduces the risk of pollinator limitation for introduced plants (Richardson et al., 2000a). See Fig. 3 for photographs of pollination biology traits associated with invasiveness in Australian acacias.

\section{Floral biology}

The fundamental floral morphology shared by all Australian acacias identifies a generalist entomophilous pollination syndrome as it provides accessible floral rewards to almost any insect visitor (Bernhardt, 1989). A second pollination 
Figure 2 Bayesian phylogenetic tree depicting relationships among taxa included in the phylogenetic generalized least-squares analysis. Numbers at nodes indicate the Bayesian posterior probability (PP). Invasive taxa are shown in red. ${ }^{\star}$ No reproductive trait data were available for A. vestita.

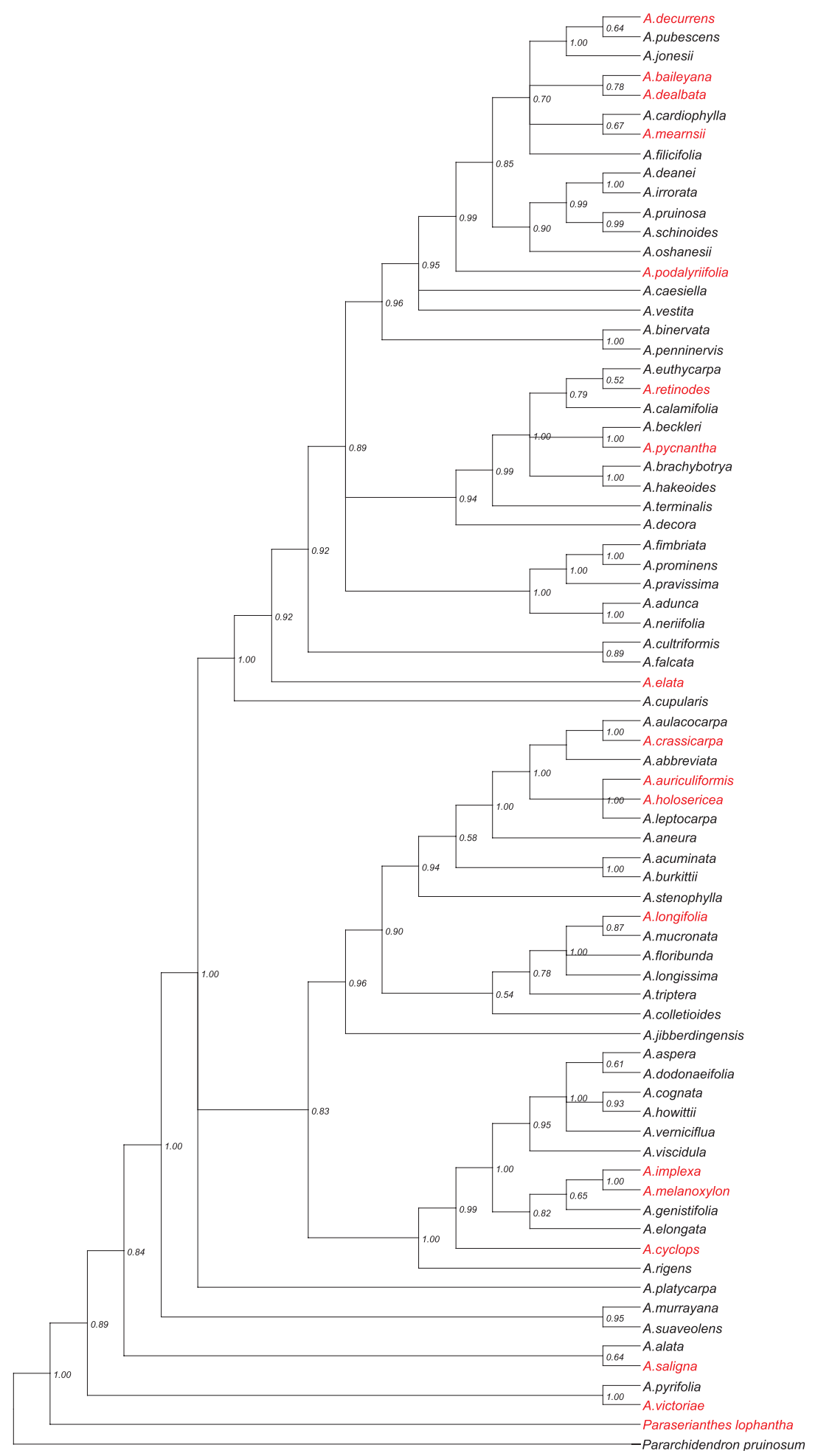

syndrome involves pollination by nectar-feeding birds and is associated with the location of a large extrafloral nectary near the inflorescence. Pollen collected on the bird's head is transferred while it feeds on the gland's nectar (Knox et al., 1985). Some species display both insect and bird pollination syndromes (e.g. A. terminalis, Kenrick et al., 1987). As with morphology, having a generalized pollination system reduces pollinator limitation of seed set and is thus likely to contribute to the invasive success of Australian acacias (Richardson et al., 2000a).

Australian acacias show two features in their floral biology that together distinguish them from all other related taxa (Stone et al., 2003). First, no Australian acacias are recorded to secrete floral nectar, although some produce extrafloral nectar 
Table 1A Phylogeny-free analyses of correlations between reproductive traits and invasiveness of 126 introduced Australian Acacia species (23 invasive/103 non-invasive Table S1).

\begin{tabular}{|c|c|c|c|c|}
\hline \multirow{2}{*}{$\begin{array}{l}\text { Explanatory variables } \\
\text { Reproductive traits }\end{array}$} & \multicolumn{2}{|l|}{ Response variables } & \multirow[b]{2}{*}{ Test } & \multirow[b]{2}{*}{ Relationship } \\
\hline & Invasive & Not invasive & & \\
\hline Continuous & \multicolumn{4}{|c|}{ Summary $(n$; mean, $\mu$; range $)$} \\
\hline $\begin{array}{l}\text { Index of self-incompatibility } \\
\text { (ISI) (infructescence/ } \\
\text { inflorescence) }\end{array}$ & $\begin{array}{l}n=6 \\
\mu=0.425 \\
\text { range }=0.02-0.86\end{array}$ & $\begin{array}{l}n=3 \\
\mu=0.42 \\
\text { range }=0.13-0.96\end{array}$ & $\begin{array}{l}\text { GLM (negative binomial errors): } \\
\mathrm{z}=0.010, P=0.992\end{array}$ & $\begin{array}{l}\text { No effect } \\
\text { No effect }\end{array}$ \\
\hline ISI (pods/inflorescence) & $\begin{array}{l}n=7 \\
\mu=0.339 \\
\text { range }=0.008-0.79\end{array}$ & $\begin{array}{l}n=3 \\
\mu=0.447 \\
\text { range }=0.07-1.1\end{array}$ & $\begin{array}{l}\text { GLM (negative binomial errors): } \\
z=-0.212, P=0.832\end{array}$ & $\begin{array}{l}\text { No effect } \\
\text { No effect }\end{array}$ \\
\hline Seed mass (mg) & $\begin{array}{l}n=23 \\
\mu=20.3 \\
\text { range }=5.7-47.8\end{array}$ & $\begin{array}{l}n=99 \\
\mu=21.1 \\
\text { range }=2.72-219\end{array}$ & $\begin{array}{l}\text { GLM (binomial errors; response var. } \\
\log 10 \text { transformed): } z=1.14 \\
P=0.254\end{array}$ & $\begin{array}{l}\text { No effect } \\
\text { No effect }\end{array}$ \\
\hline Length of flowering (months) & $\begin{array}{l}n=22 \\
\mu=4.909 \\
\text { range }=2-10\end{array}$ & $\begin{array}{l}n=59 \\
\mu=4.890 \\
\text { range }=2-12\end{array}$ & $\begin{array}{l}\text { GLM (binomial errors): } z=0.042 \\
P=0.966\end{array}$ & $\begin{array}{l}\text { No effect } \\
\text { No effect }\end{array}$ \\
\hline Binary & \multicolumn{4}{|c|}{ Summary $((n$, number of total for each factor level); mean, $\mu$; confidence interval (CI; 97.5\%)) } \\
\hline $\begin{array}{l}\text { Time to reproductive } \\
\text { maturity ( }>2 \text { years } \\
\text { or }<2 \text { years) }\end{array}$ & $\begin{array}{l}n=13 \\
(10<2 \text { years, } \\
3>2 \text { years }) \\
\mu=77 \%<2 \text { years } \\
\text { CI }=54-100 \%\end{array}$ & $\begin{array}{l}n=26 \\
(7,<2 \text { years, } 19 \\
>2 \text { years }) \\
\mu=27 \%<2 \text { years } \\
\text { CI }=12-46 \%\end{array}$ & $\begin{array}{l}\text { Chi-square: } \chi^{2}=6.90, \text { d.f. }=1, \\
P=0.0086\end{array}$ & $\begin{array}{l}\text { Invasive species reach } \\
\text { reproductive } \\
\text { maturity earlier than } \\
\text { non-invasive species }\end{array}$ \\
\hline $\begin{array}{l}\text { Combined measure of } \\
\text { breeding system ('mixed" } \\
\text { or 'outcrossing') }\end{array}$ & $\begin{array}{l}n=10(2 \text { mixed, } 8 \\
\text { outcross }) \\
\mu=20 \% \text { mixed } \\
\text { CI }=0-50 \%\end{array}$ & $\begin{array}{l}n=3(1 \text { mixed, } 2 \\
\text { outcross }) \\
\mu=50 \% \text { mixed } \\
\text { CI }=0-100 \%\end{array}$ & $\begin{array}{l}\text { Chi-square: } \chi^{2}=0.0903, \text { d.f. }=1 \text {, } \\
P=0.764\end{array}$ & No effect \\
\hline $\begin{array}{l}\text { Seed dispersal ('bird' or } \\
\text { 'not bird') }\end{array}$ & $\begin{array}{l}n=15(8 \text { bird, } 7 \text { not } \\
\text { bird }) \\
\mu=53 \% \text { bird } \\
\text { CI }=27-80 \%\end{array}$ & $\begin{array}{l}n=12(4 \text { bird, } 8 \\
\text { not bird }) \\
\mu=33 \% \text { bird } \\
\text { CI }=8-58 \%\end{array}$ & $\begin{array}{l}\text { Chi-square: } \chi^{2}=0.422 \text {, d.f. }=1 \text {, } \\
P=0.516\end{array}$ & No effect \\
\hline $\begin{array}{l}\text { Ability to resprout } \\
\text { (True/False) }\end{array}$ & $\begin{array}{l}n=21(11 \text { can resprout, } \\
10 \text { cannot }) \\
\mu=52 \% \\
\text { CI }=33-71 \%\end{array}$ & $\begin{array}{l}n=54(13 \text { can } \\
\text { resprout, } 41 \text { cannot }) \\
\mu=24 \% \\
\text { CI }=13-35 \%\end{array}$ & $\begin{array}{l}\text { Chi-square: } \chi^{2}=4.34, \text { d.f. }=1 \text {, } \\
P=0.037\end{array}$ & $\begin{array}{l}\text { Ability to resprout } \\
\text { significantly positively } \\
\text { related to species } \\
\text { being invasive }\end{array}$ \\
\hline
\end{tabular}

Details of actual parameter estimates are given in Appendix S2.

to attract insect and bird pollinators (Knox et al., 1985; Vanstone \& Paton, 1988). There are also other acacia (Acacia s.l.) species that lack nectar, including $A$. nilotica (Stone et al., 1998) - the most invasive African acacia in Australia (Radford et al., 2002). A second distinctive feature is that individual flowers and flower heads are relatively long-lived in Australian acacias (Prescott, 2005) compared with other acacias. Flowers on a single flower head open over a series of days, and each flower head can last for up to two weeks (Stone et al., 2003; George et al., 2009). Intuitively, floral longevity should contribute to the success of Australian acacias as invaders, because long-lived flowers are tolerant of competition and have a higher probability of pollination when pollination events are rare because of pollinator or mate limitation.

The ability of introduced Australian acacias to tolerate competition for pollination is likely to facilitate invasion, as introduced species enter an environment where all pollinators have established relationships with other plant species (Pyšek et al., 2011). Flower heads of Australian acacias open gradually and asynchronously, which favours foraging by small bees that can gather resources in small packets (Stone et al., 2003). Acacia flowers can be either male-only or hermaphrodite (Kenrick, 2003; George et al., 2009). Australian Acacia species have strictly protogynous flowers where the stigma is receptive 
Table 1B Comparison of phylogeny-controlled and phylogeny-free analyses of relationships between reproductive traits and invasiveness for 72 introduced Australian Acacia species (cf. 126 species in Table 1A), comprising 17 invasive and 55 non-invasive species.

\begin{tabular}{|c|c|c|c|c|c|}
\hline \multirow{2}{*}{$\begin{array}{l}\text { Explanatory variables } \\
\text { Reproductive traits }\end{array}$} & \multicolumn{2}{|l|}{ Response variables } & \multirow[b]{2}{*}{ Test } & \multirow{2}{*}{$\begin{array}{l}\text { Phylogenetic } \\
\text { generalized } \\
\text { least squares }\end{array}$} & \multirow[b]{2}{*}{ Relationship } \\
\hline & Invasive & Not invasive & & & \\
\hline Continuous & \multicolumn{2}{|c|}{ Summary ( $n$; mean, $\mu$; range) } & & & \\
\hline $\begin{array}{l}\text { ISI (Index of } \\
\text { self-incompatibility) } \\
\text { (infructescence/ } \\
\text { inflorescence) }\end{array}$ & $\begin{array}{l}n=5 \\
\mu=0.34 \\
\text { range }=0.02-0.78\end{array}$ & $\begin{array}{l}n=1 \\
\mu=0.13 \\
\text { range }=0.13\end{array}$ & $\begin{array}{c}\text { GLM (binomial errors): } \\
\mathrm{z}=0.522, P=0.602\end{array}$ & $\begin{array}{l}t=0.107 \\
P=0.920\end{array}$ & $\begin{array}{l}\text { No effect with or without } \\
\text { phylogeny }\end{array}$ \\
\hline ISI (pods/inflorescence) & $\begin{array}{l}n=6 \\
\mu=0.26 \\
\text { range }=0.008-0.77\end{array}$ & $\begin{array}{l}n=1 \\
\mu=0.07 \\
\text { range }=0.07\end{array}$ & $\begin{array}{c}\text { GLM (binomial errors): } \\
z=0.475, P=0.635\end{array}$ & $\begin{array}{l}t=0.139 \\
P=0.895\end{array}$ & $\begin{array}{l}\text { No effect with or without } \\
\text { phylogeny } \\
\text { No effect with or without } \\
\text { phylogeny }\end{array}$ \\
\hline Seed mass (mg) & $\begin{array}{l}n=17 \\
\mu=20.34 \\
\text { range }=7.52-40.55\end{array}$ & $\begin{array}{l}n=53 \\
\mu=23.16 \\
\text { range }=5.21-219.77\end{array}$ & $\begin{array}{l}\text { GLM (binomial errors); } \\
\text { response var. } \log 10 \\
\text { transformed): } z=0.777 \text {, } \\
P=0.437\end{array}$ & $\begin{array}{l}t=0.1 .01 \\
P=0.315\end{array}$ & $\begin{array}{l}\text { No effect with or without } \\
\text { phylogeny } \\
\text { No effect with or without } \\
\text { phylogeny }\end{array}$ \\
\hline $\begin{array}{l}\text { Length of flowering } \\
\text { (months) }\end{array}$ & $\begin{array}{l}n=16 \\
\mu=4.63 \\
\text { range }=2-10\end{array}$ & $\begin{array}{l}n=39 \\
\mu=4.80 \\
\text { range }=2-12\end{array}$ & $\begin{array}{c}\text { GLM (binomial errors): } \\
z=-0.330, P=0.741\end{array}$ & $\begin{array}{l}t=-0.077 \\
P=0.939\end{array}$ & $\begin{array}{l}\text { No effect with or without } \\
\text { phylogeny }\end{array}$ \\
\hline Binary & \multicolumn{5}{|c|}{ Summary $((n$, number of total for each factor level); mean, $\mu$; confidence interval (CI; 97.5\%)) } \\
\hline $\begin{array}{l}\text { Time to reproductive } \\
\text { maturity }\end{array}$ & $\begin{array}{l}n=10(8<2 \text { years, } \\
2>2 \text { years }) \\
\mu=75 \%<2 \text { years } \\
\mathrm{CI}=50-100 \%\end{array}$ & $\begin{array}{l}n=16(7,<2 \text { years, } \\
19,>2 \text { years }) \\
\mu=48 \%<2 \text { years } \\
\text { CI }=19-69 \%\end{array}$ & $\begin{array}{l}\text { Chi-square: } \chi^{2}=5.44 \\
\text { d.f. }=1, P=0.02\end{array}$ & $\begin{array}{l}t=-3.18 \\
P=0.004\end{array}$ & $\begin{array}{l}\text { Invasive species reach } \\
\text { reproductive maturity } \\
\text { earlier than non-invasive } \\
\text { species with and without } \\
\text { phylogeny }\end{array}$ \\
\hline $\begin{array}{l}\text { Combined measure of } \\
\text { breeding system }\end{array}$ & $\begin{array}{l}n=9(1 \text { mixed } \\
8 \text { outcross }) \\
\mu=17 \% \text { mixed } \\
\text { CI }=0-33 \%\end{array}$ & $\begin{array}{l}n=1(1 \text { outcross }) \\
\mu=100 \% \text { mixed } \\
C I=100 \%\end{array}$ & $\begin{array}{l}\text { Chi-square: } \chi^{2}=1.98 \\
\text { d.f. }=1, P=0.16\end{array}$ & $\begin{array}{l}t=-0.103 \\
P=0.920\end{array}$ & $\begin{array}{l}\text { No effect with or without } \\
\text { phylogeny }\end{array}$ \\
\hline Seed dispersal & $\begin{array}{l}n=12(6 \text { bird, } 6 \\
\text { not bird }) \\
\mu=49 \% \text { bird } \\
C I=23-75 \%\end{array}$ & $\begin{array}{l}n=5(2 \text { bird, } 3 \\
\text { not bird }) \\
\mu=40 \% \text { bird } \\
\text { CI }=0-80 \%\end{array}$ & $\begin{array}{l}\text { Chi-square: } \chi^{2}=0.02 \text {, } \\
\text { d.f. }=1, P=0.88\end{array}$ & $\begin{array}{l}t=-0.024 \\
P=0.981\end{array}$ & $\begin{array}{l}\text { No effect with or without } \\
\text { phylogeny }\end{array}$ \\
\hline Ability to resprout & $\begin{array}{l}n=15(9 \text { can } \\
\text { resprout, } 6 \text { cannot }) \\
\mu=60 \% \\
\mathrm{CI}=33-87 \%\end{array}$ & $\begin{array}{l}n=34(7 \text { can } \\
\text { resprout, } 27 \text { cannot }) \\
\mu=23 \% \\
\text { CI }=9-35 \%\end{array}$ & $\begin{array}{c}\text { Chi-square: } \chi^{2}=5.67 \\
\text { d.f. }=1, P=0.0 .02\end{array}$ & $\begin{array}{l}t=1.08 \\
P=0.287\end{array}$ & $\begin{array}{l}\text { Ability to resprout } \\
\text { significantly positively } \\
\text { related to species being } \\
\text { invasive, but significance } \\
\text { lost when phylogeny } \\
\text { considered }\end{array}$ \\
\hline
\end{tabular}

Phylogenetic relationships among species were incorporated as a covariate in a generalized least-squares analysis (see Methods). Actual parameter estimates are given in Appendix S3.

before the anthers produce pollen (Stone et al., 2003; George et al., 2009). In contrast, the flower heads of African and American acacias are protandrous and release pollen synchronously, which makes them attractive to larger native bee species because all the resource is presented at once (Stone et al., 2003; Raine et al., 2007). To exploit this larger food resource effectively, the larger African bees, which are important pollinators of African acacias, time their arrival at each species to coincide with its daily pollen release (Stone et al., 1998). This foraging behaviour would be ineffective for the exploitation of Australian acacia flowers, and it is not surprising that the most prominent visitors to introduced 

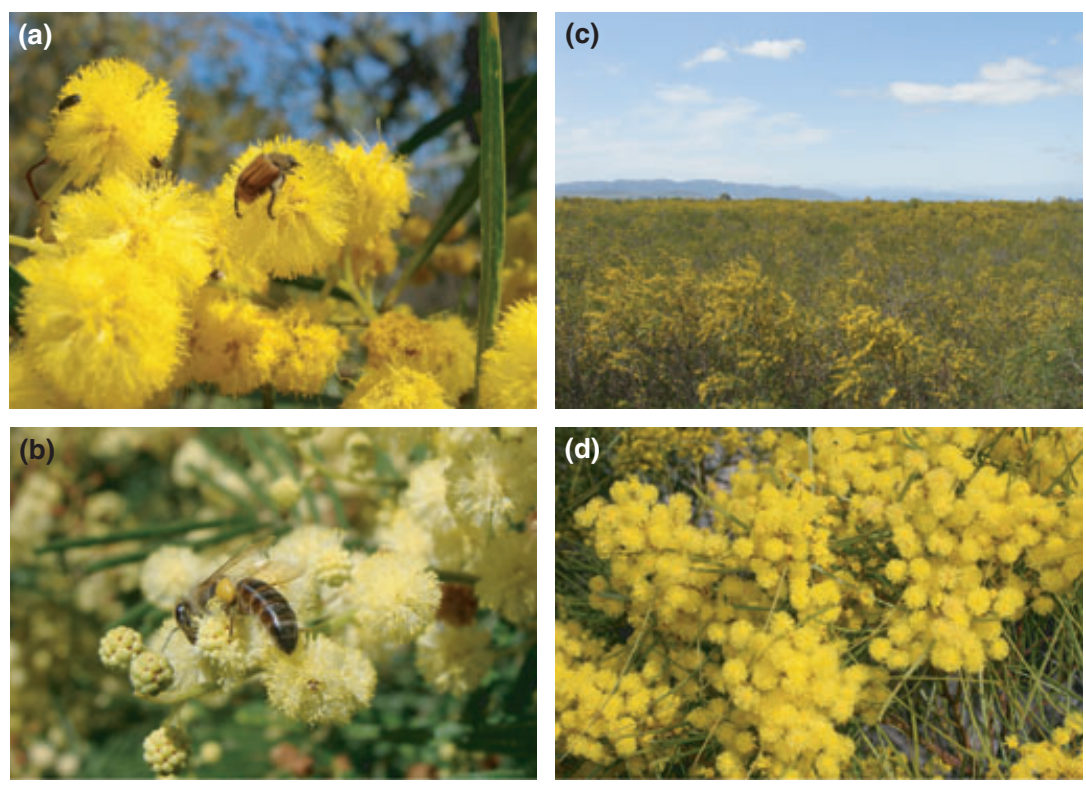

Figure 3 Important pollination biology traits associated with invasiveness in Australian acacias. These species share a generalist pollination syndrome as illustrated in South Africa where (a) Acacia saligna is being visited by native beetles (photograph: M.R. Gibson) and (b) A. mearnsii is being visited by the native honeybee, Apis mellifera capensis (photograph: A.M. Rogers). (c) Mass flowering in a field invaded by A. saligna in South Africa during its flowering peak in September (photograph: A.M. Rogers). (d) The dense flowers of A. adunca form an eye-catching, bright yellow floral display in Queensland (photograph: T. Low).
Australia acacias are often honeybees (Apis mellifera) (Bernhardt, 1987; Sedgley et al., 1992; Sornsathapornkul \& Owens, 1998; Alves \& Marins-Corder, 2009), whose sensitivity to resource availability and ability to learn are both exceptional among bees (Willmer \& Stone, 2004).

Other floral traits that may contribute to the invasive success of Australian acacias are precocity (early reproductive maturity) and longevity. Morgan et al. (2002) found that low final pod set (pods/inflorescence) in A. baileyana, as is seen in many acacias (Kenrick, 2003), was offset by precocious flowering and high flower numbers, which resulted in high seed production, probably partly facilitating its invasiveness. Early reproductive maturity is seen in many invasive acacias with some commencing flowering at just two years of age (see Table S1). In this study, both phylogeny-free and phylogenetic analyses suggested that short juvenile period was a significant factor distinguishing invasive acacias from non-invasive species. This result makes intuitive sense, because shorter juvenile periods enhance invasiveness by ensuring that seeds are produced sooner and thus confer an overall high seed production and allow for rapid accumulation of a soil seed bank. On a coarse level, floral biology appears essentially similar for all Australian acacias. Consequently, specific traits such as time of pollen release and inflorescence longevity are unlikely to distinguish invasive and non-invasive Australian acacias. However, subtle variations in combinations of sexual receptiveness and longevity (e.g. age-dependent floral colour variation; M.N. Prescott, unpublished data) could be important in this regard and require proper studies before being fully ruled out.

\section{Pollination and pollen vectors}

Pollinator assemblages vary on an annual, seasonal and geographic basis so that a diverse spectrum of floral foragers visit Acacia species in a given location, but the dominance of specific vectors can vary inter- and intraspecifically (Bernhardt, 1989). In their native range, Acacia species are visited by a variety of flower foragers, but the most important pollinators are usually bees and wasps (Apoidea), followed by flies, beetles and birds (Kenrick et al., 1987; Vanstone \& Paton, 1988; Bernhardt, 1989; Stone et al., 2003; Prescott, 2005). Social bees are relatively scarce in Australia, and most of the dominant native bees are small-bodied polylectic solitary species in the families Anthophoridae, Colletidae and Halictidae. The introduced honeybee is also an important and abundant pollinator of Australian acacias in both their native and introduced ranges (Bernhardt, 1987; Thorp \& Sugden, 1990; Sedgley et al., 1992; Prescott, 2005). Existing studies of introduced Australian acacias in South Africa show that native honeybees (Apis mellifera capensis and A. mellifera scutellata) are dominant pollen vectors followed to a lesser extent by flies and bees (M.R. Gibson, unpublished data; J.G. Rodger unpublished data) (see Table S3 for a comprehensive list of flower visitors). In other parts of the introduced range of Australian acacias, honeybees tend to be the most abundant and effective floral visitor in terms of visitation frequency and pollen-carrying load (Sornsathapornkul \& Owens, 1998), although their distribution may be restricted to areas with sufficient availability of nectar flowers (Alves \& Marins-Corder, 2009). Honeybees may be especially important for pollination in the context of Acacia invasions as they can learn to exploit new floral resources in a matter of hours (Willmer \& Stone, 2004).

The importance of biotic pollination for reproductive success depends on whether abiotic pollination occurs. Although it remains to be tested and although pollen has been collected downwind of flowering A. mearnsii (Wattle Research Institute, 1952; Moncur et al., 1989), Acacia inflorescences show no apparent adaptations for capture of windborne pollen. In contrast to typical wind-pollinated species, which have feathery stigmas and aerodynamic features that aid 
in capture of pollen grains (Niklas, 1985, 1987), Acacia flowers have a very small cup-shaped stigma into which only one polyad can fit and lack any obvious aerodynamic structures. Wind-pollinated species have relatively high pollen to ovule ratios (median 22 150: 1) relative to animal-pollinated species (median 3450:1), although pollen-transfer efficiencies (proportion of removed pollen that is captured by stigmas) are similar (Friedman \& Barrett, 2009). Typical of plants with aggregated (i.e. polyad-like) pollen (Harder \& Johnson, 2008), the pollen to ovule ratio in Acacia is very low (53-360 for A. mearnsii based on measurements in Kenrick \& Knox, 1982; Moncur et al., 1991), compatible with dependence on animal pollen vectors. While it thus seems unlikely that wind pollination would make an appreciable contribution to fecundity, the possibility cannot yet be rejected. In the only test for wind pollination that we are aware of, fruit set of A. mearnsii was reduced but not eliminated in inflorescences enclosed in cages of wire and nylon mesh. However, bags reduced wind-borne pollen supply, and some flowers may have protruded through the cages and been pollinated by bees (Wattle Research Institute, 1952, 1961) so decisive experiments are still required to assess whether wind pollination is at all important for Acacia.

Because acacias are pollinated by generalist pollinators (such as the widely introduced honeybee), pollinator limitation seems an unlikely constraint to the spread of introduced Australian acacias relative to non-invasive taxa (Richardson et al., 2000a) but this has not yet been studied. If pollination by A. mellifera enhances seed production of Australian acacias, then honeybees could facilitate Acacia invasions (and the facilitation could be reciprocal where both species are introduced, as in South America) (Barthell et al., 2001; Morales \& Aizen, 2002). We conclude that generalist pollination facilitates invasion, but there is no evidence to suggest that this factor alone explains the relative success of different Australian acacias as invasive and introduced non-invasive species both possess generalist pollination systems.

\section{Phenology}

Most Australian acacias tend to flower in massive displays from late winter to mid-spring (Bernhardt, 1989; Costermans, 2007) and have long-lived (and so competition tolerant) inflorescences (Stone et al., 2003; Prescott, 2005), although the number of flower heads in bloom can fluctuate greatly depending on environmental conditions and resource availability (Sedgley, 1985; Gaol \& Fox, 2002; Yates \& Broadhurst, 2002). Pollen release often occurs in the middle of the day when insect abundance is greatest, which likely confers an advantage when it comes to adapting to new habitats in the initial stages of invasion (M.N. Prescott, unpublished data). Where Australian acacias are invasive in Mediterranean-type climate regions, their flowering occurs earlier than, and overlaps with, most native species whose peak flowering occurs in spring (Henderson, 2001; Godoy et al., 2009). Various studies have shown early and extended flowering phenologies of invasive versus native plants to be correlated with invasive potential (Cadotte \& Lovett-Doust, 2001; Pyšek \& Richardson, 2007; Pyšek et al., 2009), thus conferring a fitness advantage by reduced competition for pollinators (Stone et al., 1998; Raine et al., 2007). However, while this may be true in general, differences in overall length of flowering period between invasive and non-invasive Australian acacias were found to be non-significant (P. Castro-Díez, unpublished data; see discussion in Castro-Díez et al., 2011).

Peak flowering prior to and during spring, while not unique to invasive Australian acacias, may contribute indirectly to invasiveness in some environments as early and prolonged flowering in Acacia species during peak flowering of native species in exotic ecosystems may help mitigate pollen and pollinator limitation. Again, this alone is not likely to contribute to invasiveness but may do so when it is combined with other invasion-enhancing reproductive traits that are not present in non-invasive species.

\section{Breeding system and seed set}

Completely self-incompatible species depend entirely on pollinators and mate availability, but self-compatibility and the ability to self-pollinate autonomously assure reproduction against inadequate pollinator visitation and/or mate availability (Eckert et al., 2006). Australian Acacia species range from highly self-incompatible to completely self-compatible and autogamous (Table S1) (Moffett, 1956; Bernhardt et al., 1984; Kenrick \& Knox, 1989; Morgan et al., 2002), and so probably vary greatly in their dependence on pollinators for realized fecundity. Realized outcrossing rates tend to be high (multilocus outcrossing rate $\left(t_{\mathrm{m}}\right)>0.9$ in most species: Table S1) indicating that pollinators do play an important role in their reproduction. Partial self-compatibility and intraspecific variation in self-compatibility seem relatively common in Australian Acacia species (Philp \& Sherry, 1946; Moffett \& Nixon, 1974) with some ability to reproduce by selfing known for six species, five of which are invasive (see Table S1: Acacia dealbata, A. decurrens, A. mearnsii, A. paradoxa, A. saligna) (J.G. Rodger, unpublished data; George et al., 2008; Millar et al., 2011).

The apparently high prevalence of at least some level of selfcompatibility in Australian Acacia species is significant given the rarity of uniparental reproduction in woody plants (Barrett et al., 1996). This is consistent with the observation by Rambuda \& Johnson (2004) that all 13 woody species investigated in a survey of breeding systems of invasive plants in South Africa were capable of uniparental reproduction. Investigation of Australian Acacia species could reveal further details about the evolution of breeding systems and their role in invasiveness in woody species in general. Comparisons between invasive and non-invasive Acacia species are hindered by insufficient data here, as elsewhere, but available information suggest that invasive taxa tend to have higher levels of selfcompatibility, suggesting ability to self-fertilize may predispose Acacia species to invasiveness. However, in shade house trials, 
selfed progeny of A. mearnsii, A. decurrens (Moffett \& Nixon, 1974) and A. dealbata (J.G. Rodger, unpublished data) have reduced growth and survival, which would erode the reproductive assurance benefits of selfing (Herlihy \& Eckert, 2002). Other self-compatible tree species have such high levels of inbreeding depression that it is unlikely that progeny arising from self-pollination ever reach reproductive maturity (Hardner \& Potts, 1997; Ishida, 2006; Robertson et al., 2011). A comparison of fixation index for trees from germination to reproduction (e.g. Ishida, 2006) would reveal whether selfed progeny reach reproductive maturity and therefore whether self-compatibility potentially enhances invasiveness.

Even a low capacity for reproduction by self-fertilization could be important in alleviating pollinator and mate limitation, which are likely to occur in the early stages of naturalization and invasion owing to small size or low density of populations (Baker, 1955; Davis et al., 2004). Such factors have been shown to influence seed set in Acacia in the native range (Broadhurst \& Young, 2006). However, extensive pollen dispersal may maintain outcrossing rates in small patches or isolated plants (Millar et al., 2008, 2011). While ability to selffertilize may make species more likely to become invasive or to spread at greater rates, it is not essential for invasiveness - there are prominent examples of invasive self-incompatible species in Acacia (e.g. A. auriculiformis, A. pycnantha - see Table S1) and other groups (e.g. Barthell et al., 2001). Our study found no differences in indices of self-compatibility (ISI) nor breeding system strategy (mixed versus outcrossing) between invasive and non-invasive species (Table $1 \mathrm{~A}, \mathrm{~B}$ ), though data for these traits were extremely limited (see Table S1).

\section{Seed biology}

Seed biology seems to be one of the most important factors contributing to the invasion success of Australian acacias (Milton \& Hall, 1981; Richardson \& Kluge, 2008). Seed biology syndromes in many Acacia species are largely shaped by firedriven ecosystems that are present throughout much of Australia and introduced Mediterranean-type climate regions. Fire-adaptive traits include: production of large quantities of hard-coated, heat-tolerant and long-lived seeds with the capacity for long dormancy; stimulation of germination by heat and/or smoke; seed dispersal and burial by ants; and the ability to resprout (Berg, 1975; Bell et al., 1993; Specht \& Specht, 1999), all of which are likely essential for the persistence and invasive success of Australian acacias (see Fig. 4 for photographs of seed biology traits associated with invasiveness).

\section{Dispersal}

Dispersal is a crucial aspect of progression from 'naturalized' to 'invasive' status when recruitment occurs at considerable distances from parent plants (Richardson et al., 2000a,b). Australian acacias possess seed adaptations for dispersal by birds and ants (Davidson \& Morton, 1984; O’Dowd \& Gill,
1986), although passive dispersal via water, wind and gravity is also common.

Broadly, biotic seed dispersal in Acacia falls into two syndromes based on features of arils: a 'bird-dispersal syndrome' and an 'ant-dispersal syndrome' (O'Dowd \& Gill, 1986). The fleshy arillate appendages (in bird-dispersed seeds) and an elaiosome (in ant-dispersed seeds) attach the seed to the seed pod lining and make them accessible to a range of bird and ant species across multiple foraging types. Such generalization of morphological traits associated with dispersal makes limitation of a seed dispersal agent in the introduced range unlikely (see Glyphis et al., 1981; Holmes, 1990a; Richardson et al., 2000a; Underhill \& Hofmeyr, 2007). Furthermore, these traits may be evolutionarily labile since A. ligulata reportedly displays both syndromes (Davidson \& Morton, 1984), each of which has its own advantages. Birds are important agents in that they aid in longer distance dispersal (Holmes, 1990a) and, through ingesting the seeds, are able to aid in the germination of Acacia species requiring chemical scarification (e.g. A. cyclops, A. melanoxylon) (Glyphis et al., 1981; Richardson \& Kluge, 2008). Ants rapidly remove and bury Acacia seeds in subterranean nests and so contribute to dispersal on a local scale (Holmes, 1990a). Species noted as having a 'birddispersal syndrome' are likely also dispersed vertically by ants, as myrmecochory accounts for much of the movement of seed from the litter layer into the seed bank (Richardson \& Kluge, 2008). Dispersal by birds of an 'ant-dispersal syndrome' species appears less likely (O’Dowd \& Gill, 1986).

Importantly, seed morphology and dispersal agents in the native range of Australian acacias are not always accurate predictors of dispersal agents in introduced ranges. For example, in Portugal, South Africa and Florida, invasive Acacia seeds are effectively dispersed by a wide range of opportunistic agents besides those that one would consider functional equivalents of dispersal agents in the native range. These include baboons, domestic and wild ungulates and humans (Ridley \& Moss, 1930; Middlemiss, 1963; Kull \& Rangan, 2008). In the Western Cape of South Africa, primarily insectivorous barn swallows ingest seeds and act as effective dispersal agents of A. cyclops (Underhill \& Hofmeyr, 2007), and other granivorous, ground-dwelling birds disperse Acacia seeds (Duckworth \& Richardson, 1988; Knight \& Macdonald, 1991). In New Zealand, most native avian seed dispersers are now extinct (Anderson et al., 2006), and the ant fauna is relatively depauperate and limited in distribution (Don, 2007), with only three ant species including seeds in their diet. Despite these limitations, at least eight Australian Acacia species have become invasive in New Zealand (Richardson \& Rejmánek, 2011) with A. baileyana showing evidence of long-distance dispersal although the dispersal agent is not known (E.M. Wandrag, unpublished data). Furthermore, in many humandominated systems, long-distance dispersal of introduced species is mostly human mediated (Trakhtenbrot et al., 2005), so this distinction is likely less important in determining spread rates than may be predicted.

Abiotic dispersal in water and soil is important in many regions (Milton \& Hall, 1981). There is a strong association 

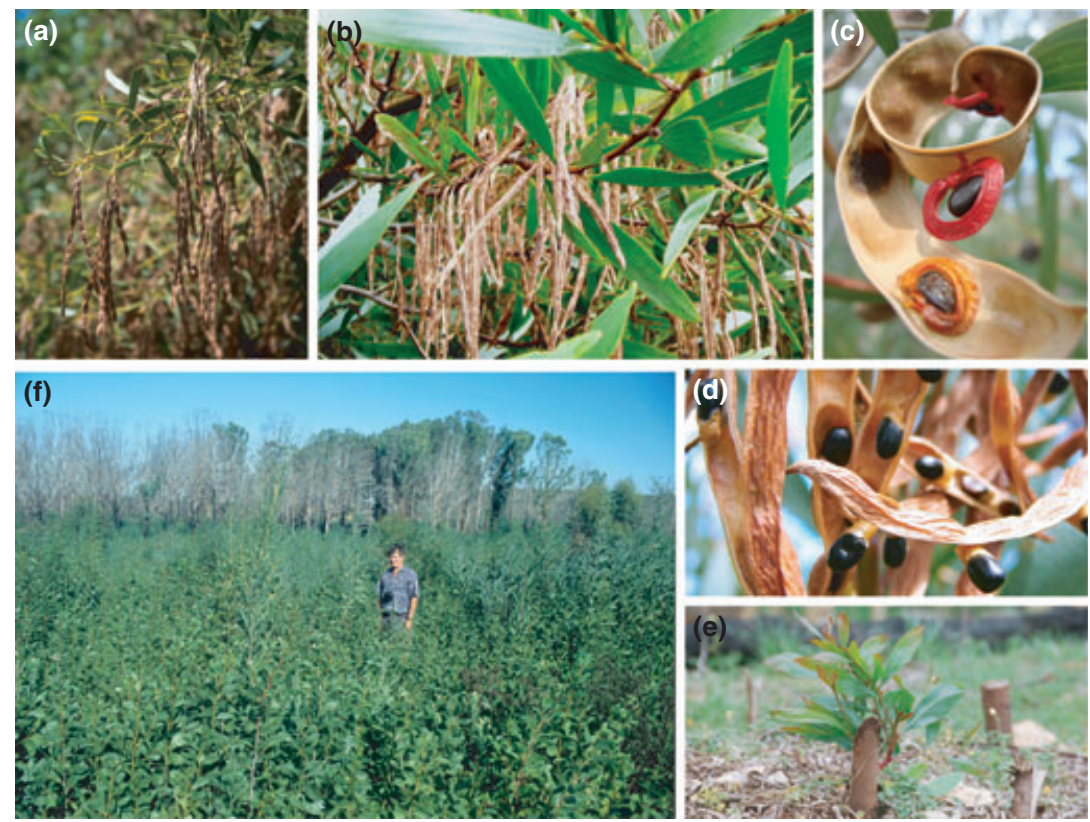

Figure 4 Important seed biology traits associated with invasiveness in Australian acacias. (a) Seed production of Acacia saligna in South Africa during the early 1980s, prior to the introduction of the rust fungus Uromycladium uromyces, which has since greatly reduced seed production (photograph: D.M. Richardson). (b) Seed production of A. longifolia in its native range in Australia (photograph: C. Harris). Seeds that fall to the ground can remain viable for $50+$ years, making their eradication nearly impossible. (c) A. cyclops seeds remain in the tree canopy longer than those of species that are typically ant-dispersed; the bright red aril attracts birds that disperse the seeds (photograph: A.M. Rogers). (d) A. longifolia seeds are typically ant-dispersed in the native range, although bird-dispersal is predicted based on aril attributes; they are attached to the seed pod by an elaiosome that attracts ants (photograph: C. Harris). (e) Invasive species, such as A. saligna pictured here, have a greater tendency to resprout following a disturbance event than non-invasive species (photograph: D.M. Richardson). (f) The mass germination of Acacia seeds after fire, as in A. pycnantha in South Africa shown here, is a major hurdle to control efforts (photograph: D.M. Richardson).

between $A$. dealbata invasions and watercourses in Chile and Portugal (H. Marchante, unpublished data; Pauchard et al., 2008). Movement of soil for road building is also a major dispersal route of $A$. dealbata and A. longifolia in Portugal (H. Marchante, unpublished data). Similarly in South Africa, rivers and soil movement aid in the dispersal of acacias that invade riparian areas, such as A. mearnsii (de Wit et al., 2001).

Seed mass in Acacia was found to be positively correlated with invasiveness in a recent study (Castro-Díez et al., 2011) but did not consistently differ in our study nor in a multispecies study comparing seed mass between native and introduced ranges (C. Harris et al., unpublished data). These results contradict findings for Pinus where smaller seed size is positively associated with invasiveness, as small seeds are more suitable for long-distance dispersal by wind (Richardson, 2006). The difference between pines and acacias in this regard is not surprising. Unlike pines, most acacias are animal dispersed, and dispersal by wind is of trivial importance. Factors other than size contribute to dispersibility, and seed size plays an entirely different role as mediator of colonization and establishment success.

Dispersal traits associated with a bird-dispersed syndrome in Australian acacias clearly predispose these species to spread rapidly in a new environment (see discussion of this for A. cyclops in South African fynbos by Higgins et al., 2001) because of the importance of long-distance dispersal events in driving invasions (Trakhtenbrot et al., 2005). However, of the 23 species of Australian Acacia considered invasive (sensu Pyšek et al., 2004; Richardson \& Rejmánek, 2011), only eight species are known to be bird-dispersed or possess typical bird-dispersed seed traits (Davidson \& Morton, 1984; O’Dowd \& Gill, 1986; Langeland \& Burks, 1998; Stanley \& Lill, 2002): Acacia auriculiformis, A. cyclops, A. holosericea, A. implexa, A. longifolia, A. mangium, A. melanoxylon and A. salicina (see Table S1). Additionally, our analysis found that seed dispersal by birds was not significantly correlated with invasiveness. In Portugal, two of the most invasive and widespread Acacia species (A. dealbata and $A$. longifolia) are ant-dispersed (Marchante et al., 2010), as are A. saligna and A. mearnsii in South Africa (French \& Major, 2001; Richardson \& Kluge, 2008). Thus, the contribution of different dispersal agents to invasiveness remains unclear but further suggests a role of human-mediated dispersal and interactions with environmental factors.

\section{Seed bank dynamics}

A reproductive trait that strongly influences invasiveness of Australian acacias is their capacity to form extensive and persistent soil seed banks (Richardson \& Kluge, 2008). Accumulation times differ depending on the species (see 
Table 2 of Richardson \& Kluge, 2008), and the average shortest time frame is roughly eight years. The seeds of some Acacia species that have become invasive can remain dormant for 50100 years or more (Farrell \& Ashton, 1978; New, 1984). Richardson \& Kluge (2008) list four main factors that contribute to the size of soil-stored seed banks in Australian acacias in South Africa: the annual seed rain; the age of the stand; stand density or canopy cover; and distance from the canopy. Additional factors include level of granivory, decay and germination (Marchante et al., 2010). Biological control agents that negatively affect flower, flower bud or pod production, such as Melanterius weevils (Dennill \& Donnelly, 1991; Impson et al., 2004) that directly feed on acacia seeds, can reduce annual seed rain. The rate of seed accumulation in the soil increases until the stand is about 30 years old, and denser stands produce more seeds, so control efforts to reduce seed production should focus on younger, denser Acacia stands (Milton \& Hall, 1981; Holmes, 1990b). Seed density in the soil is highest under the tree canopy and decreases sharply with distance (see Zenni et al., 2009; Marchante et al., 2010), although Marchante et al. (2010) found a few seeds of A. longifolia up to $7 \mathrm{~m}$ from the edge of invaded stands.

The main drivers of seed bank persistence and maintenance appear to be ants, although gravity and water may be the dominant drivers where ants are absent. Once seeds have dropped to the ground, ants bury many of them in their nests to allow them to exploit arils (Milton \& Hall, 1981). In doing so, they often account for the majority of vertical seed movement into the upper seed bank. Acacia seeds gain a threefold advantage through protection from above-ground seed predators, protection from fire and incorporation into the seed bank (Gill, 1985; Holmes, 1990a). In South Africa, ants may play a critical role in accumulating seed banks of Australian acacias and aiding in their invasiveness (Holmes, 1990c; Richardson et al., 2000a).

The role of seed bank density in Acacia invasiveness is unclear. Both higher and lower seed bank densities have been recorded in the introduced range of various Acacia species when compared to that in the native range (Milton \& Hall, 1981; Richardson \& Kluge, 2008; Marchante et al., 2010). Additionally, methods of measuring seed bank and seed rain vary widely, making comparisons between introduced and native ranges problematic (see Table 2 for a summary of Australian Acacia seed data from various introduced and native regions). Prolific seed production and large accumulations of seeds in the seed bank certainly contribute to a species' ability to invade an ecosystem but these qualities alone do not guarantee invasiveness. Buist (2003) found that closely related pairs of rare and widespread Acacia species produced similar numbers of seeds and similar-sized, persistent soil seed reserves, indicating that level of seed production does not necessarily determine abundance of a species. These traits likely need to work in concert with certain physiological and morphological traits, such as germination ability, resource utilization, rapid growth of seedlings and dispersal investment, to contribute to invasiveness.

\section{Germination}

The majority of invasive Acacia species possess seeds whose germination is stimulated by fire, but some invasive species, notably bird-dispersed taxa, may be stimulated to germinate through chemical scarification via ingestion by an appropriate dispersal agent (Glyphis et al., 1981; Fraser, 1990; Richardson \& Kluge, 2008). These stimuli are required to break physical dormancy of the hard, water impermeable seed coat and allow germination of Acacia seeds, which have consistently high viability and low germinability over time. However, in Portugal, total viability and germinability were found to be significantly higher (and dormancy lower) in seeds from recently invaded soils for A. longifolia (Marchante et al., 2010).

Invasive Australian acacias tend to germinate after disturbance, although disturbance is not essential. Acacia dealbata shows high survival within native forest and in open areas in Chile where it can endure long periods of drought and shade under canopies of native trees (Fuentes-Ramírez et al., 2011). Moreover, mutualistic relationships with nitrogen-fixing bacteria are important for successful establishment of leguminous species, so the presence of compatible rhizobia is also essential for determining the colonization ability of introduced species (Parker et al., 2006; Rodríguez-Echeverría et al., 2011). Interestingly, Rodríguez-Echeverría et al. (2011) found that these bacterial symbionts are often cointroduced with their Acacia hosts from Australia, suggesting the presence of suitable soil symbionts in the introduced range may not be an important limiting factor in Acacia invasions per se.

Studies from the introduced ranges of Australian acacias report that a considerable number of seeds produced and allocated to seed rain are lost to factors such as early germination, granivory or decay (Marchante et al., 2010). However, the consistently high seed viability found in many species of Acacia appears to be fundamental to their ability to invade (see Table 2) (Richardson \& Kluge, 2008; Marchante et al., 2010). Germination characters per se do not appear to be characteristic of invasiveness as invasive Australian Acacia species in South Africa can show opposing characteristics of either high dormancy, low germination and decay rates and rapid seed bank accumulation, or low dormancy, high germination and decay rates and gradual seed bank accumulation (Richardson \& Kluge, 2008).

Comparisons of rare and widespread species show some association with factors that influence seed germination. The burial depth and heat-stimulation requirements of a species are important factors affecting germination that can determine how rare or widespread it is (Brown et al., 2003). Comparisons of reproductive traits in two rare acacias and their common relatives showed differences in the germination (reduced range of temperature for germination in rare species) and higher rates of predation of fruit and seed in the rare species (Buist, 2003). Seed viability and dormancy levels between invasive and non-invasive species have not been compared. It may be predicted that, because such traits are adaptations to 
Table 2 Seed rain density (SRD), seed bank density (SBD) and seed viability (SV) for Australian acacias in native and introduced ranges.

\begin{tabular}{|c|c|c|c|c|c|c|}
\hline Acacia species & $\begin{array}{l}\text { Seed rain density } \\
\text { per } \mathrm{m}^{2} \text { per year (SRD) }\end{array}$ & $\begin{array}{l}\text { Seed bank density } \\
\text { per } \mathrm{m}^{2}(\mathrm{SBD})\end{array}$ & $\begin{array}{l}\text { Seed viability } \\
\text { (SV) }\end{array}$ & Region & References & Observations \\
\hline A. baileyana & 19559 & - & - & $\begin{array}{l}\text { Australia } \\
\text { (native range) }\end{array}$ & 17 & SRD - maximum \#seed/tree \\
\hline A. baileyana & $1824(3010)$ & - & - & New Zealand & 26 & $\begin{array}{l}\text { SRD - average \# seeds per } \\
\mathrm{m}^{2} \text { averaged over } 7 \text {-day } \\
\text { period }\end{array}$ \\
\hline A. cyclops & - & $1430-5140(142-281)$ & $46-95.3 \%$ & South Africa & 10 & \\
\hline A. cyclops & - & 2832-7792 (402-1019) & $99.2 \%$ & South Africa & 8 & $\begin{array}{l}\text { SBD - range of four } \\
\text { different blocks }\end{array}$ \\
\hline A. cyclops & $1197\left[1373-3019^{*}\right]$ & 2031 & $87 \%$ & South Africa & 15 & $\begin{array}{l}\text { SRD }-{ }^{*} \text { estimated \#seed } \\
\text { per } \mathrm{m}^{2} \text { projected canopy }\end{array}$ \\
\hline A. cyclops & $540(710)$ & - & - & $\begin{array}{l}\text { Australia } \\
\text { (introduced } \\
\text { range) }\end{array}$ & 6 & $\begin{array}{l}\text { SRD - estimated from } \\
\text { reproductive output data } \\
\text { (determined by dividing } \\
\text { total mass of seeds } \\
\text { removed from pods by } \\
\text { mass per individual seed) }\end{array}$ \\
\hline A. cyclops & $1900(1930)$ & - & - & $\begin{array}{l}\text { Australia } \\
\text { (native range) }\end{array}$ & 6 & \\
\hline A. dealbata & - & 10000 & $90 \%$ & Chile & 25 & \\
\hline A. dealbata & $2553(3244)$ & - & - & New Zealand & 26 & $\begin{array}{l}\text { SRD - average \# seeds per } \\
\mathrm{m}^{2} \text { averaged over 7-day } \\
\text { period }\end{array}$ \\
\hline A. dealbata & - & ca. 22500 & $30 \%$ & Portugal & 13 & $\begin{array}{l}\text { SV: probably } \\
\text { underestimated (seeds } \\
\text { heated to } 50^{\circ} \mathrm{C} \text { without } \\
\text { scarification) }\end{array}$ \\
\hline A. elata & - & - & $50 \%$ & - & 22 & $\begin{array}{l}\text { SV - final germination } \\
\text { after scarification }\end{array}$ \\
\hline A. holosericea & - & - & $>95 \%$ & $\begin{array}{l}\text { Australia } \\
\text { (native range) }\end{array}$ & 7 & \\
\hline A. longifolia & $2000-12000$ & $500-1500$ & $>85 \%$ & Portugal & 14 & $\begin{array}{l}\text { SRD - 2000: smaller trees } \\
\text { next to the ocean } \\
\text { (windward); 12000: } \\
\text { bigger trees leeward }\end{array}$ \\
\hline A. longifolia & - & - & $>88 \%$ & Portugal & 16 & \\
\hline A. longifolia & 11500 & 34000 & - & South Africa & 19 & SRD - maximum number \\
\hline A. longifolia & - & $2078-3473(488-498)$ & $99 \%$ & South Africa & 21 & \\
\hline A. longifolia & 2923 & 7646 & $97 \%$ & South Africa & 15 & \\
\hline A. longifolia & - & $4528(1075)$ & $99 \%$ & South Africa & 4 & $\begin{array}{l}\text { After introduction of } \\
\text { biological control agent, } \\
\text { max numbers }\end{array}$ \\
\hline A. longifolia & $2530(3430)$ & - & - & $\begin{array}{l}\text { Australia } \\
\text { (introduced } \\
\text { range) }\end{array}$ & 6 & $\begin{array}{l}\text { SRD - estimated from } \\
\text { reproductive output data } \\
\text { (determined by dividing } \\
\text { total mass of seeds removed } \\
\text { from pods by mass per } \\
\text { individual seed) }\end{array}$ \\
\hline A. longifolia & $810(1180)$ & - & - & $\begin{array}{l}\text { Australia } \\
\text { (native range) }\end{array}$ & 6 & \\
\hline A. mangium & 410 & - & - & Indonesia & 23 & $\begin{array}{l}\text { SRD - estimated from seed } \\
\text { production in kg per ha } \\
\text { per year }\end{array}$ \\
\hline A. mearnsii & - & $5314 / 696$ & - & South Africa & 20 & $\begin{array}{l}\text { SBD- maximum } \\
\text { number/average }\end{array}$ \\
\hline
\end{tabular}


M. R. Gibson et al.

Table 2 Continued.

\begin{tabular}{|c|c|c|c|c|c|c|}
\hline Acacia species & $\begin{array}{l}\text { Seed rain density } \\
\text { per } \mathrm{m}^{2} \text { per year (SRD) }\end{array}$ & $\begin{array}{l}\text { Seed bank density } \\
\text { per } \mathrm{m}^{2}(\mathrm{SBD})\end{array}$ & $\begin{array}{l}\text { Seed viability } \\
\text { (SV) }\end{array}$ & Region & References & Observations \\
\hline A. mearnsii & - & 38340 & - & South Africa & 15 & \\
\hline A. mearnsii & - & - & $>83.4 \%$ & South Africa & 12 & \\
\hline A. melanoxylon & 3218 & 48739 & $70 \%$ & South Africa & 15 & $\begin{array}{l}\text { SRD \& SBD: Donald, } 1959 \\
\text { cited by Milton \& Hall, } 1981\end{array}$ \\
\hline A. melanoxylon & - & - & $85-91 \%$ & $\begin{array}{l}\text { Australia } \\
\text { (native range) }\end{array}$ & 2 & \\
\hline A. melanoxylon & $740(800)$ & - & - & $\begin{array}{l}\text { Australia } \\
\text { (introduced } \\
\text { range) }\end{array}$ & 6 & $\begin{array}{l}\text { SRD - estimated from } \\
\text { reproductive output data } \\
\text { (determined by dividing } \\
\text { total mass of seeds } \\
\text { removed from pods by } \\
\text { mass per individual seed) }\end{array}$ \\
\hline A. melanoxylon & $1160(1810)$ & - & - & $\begin{array}{l}\text { Australia } \\
\text { (native range) }\end{array}$ & 6 & \\
\hline A. paradoxa & - & 1000 & - & South Africa & 28 & \\
\hline A. paradoxa & $58 \#$ & - & - & $\begin{array}{l}\text { Australia } \\
\text { (native range) }\end{array}$ & 1 & $\begin{array}{l}\text { SRD - \#firm seed } \\
\text { production per plant }\end{array}$ \\
\hline A. pycnantha & $31 \#$ & - & $99 \%$ & $\begin{array}{l}\text { Australia } \\
\text { (native range) }\end{array}$ & 1 & \\
\hline A. saligna & - & $7920-45800(560-3220)$ & $>86 \%$ & South Africa & 10 & \\
\hline A. saligna & $2645-13472$ & - & - & South Africa & 27 & $\begin{array}{l}\text { SRD - measured in } 1989, \\
\text { ca. } 2 \text { years after } \\
\text { introduction of biocontrol } \\
\text { agent }\end{array}$ \\
\hline A. saligna & $446-3035$ & - & - & South Africa & 27 & $\begin{array}{l}\text { SRD - measured in } 2004, \\
\text { ca. } 18 \text { years after } \\
\text { introduction of biocontrol } \\
\text { agent }\end{array}$ \\
\hline A. saligna & $5443\left[10562^{\star}\right]$ & 11920 & $83 \%$ & South Africa & 15 & $\begin{array}{l}\text { SRD - \#seed/tree based on } \\
\text { few trees; }{ }^{\star} \text { estimated seed } \\
\text { per } \mathrm{m}^{2} \text { projected canopy }\end{array}$ \\
\hline A. saligna & - & $715-8097$ & - & South Africa & 9 & $\begin{array}{l}\text { SBD - after introduction of } \\
\text { biological control agent; } \\
\text { values estimated from } 4 \\
\text { places and } 3 \text { depths }\end{array}$ \\
\hline A. saligna & - & - & $>90 \%$ & Israel & 3 & \\
\hline A. saligna & - & 2000-189000 (53333) & - & South Africa & 18 & $\begin{array}{l}\text { After introduction of } \\
\text { biological control agent; } \\
\text { average from } 8 \text { sites, } \\
\text { samplings during } 6 \text { years }\end{array}$ \\
\hline A. saligna & - & $1389-3600(207-279)$ & - & $\begin{array}{l}\text { Australia, } \\
\text { New South Wales } \\
\text { (introduced range) }\end{array}$ & 24 & \\
\hline A. saligna & - & - & $73 \%$ & - & 22 & $\begin{array}{l}\text { SV - final germination } \\
\text { after scarification }\end{array}$ \\
\hline A. saligna & - & $3158-38714(1194-4006)$ & $>65 \%$ & South Africa & 11 & $\begin{array}{l}\text { SBD - range of } 4 \text { sites, } \\
\text { at } 0-15 \mathrm{~cm}\end{array}$ \\
\hline A. saligna & $760(750)$ & - & - & $\begin{array}{l}\text { Australia } \\
\text { (introduced } \\
\text { range) }\end{array}$ & 6 & $\begin{array}{l}\text { SRD - estimated from } \\
\text { reproductive output data } \\
\text { (determined by dividing } \\
\text { total mass of seeds removed } \\
\text { from pods by mass per } \\
\text { individual seed) }\end{array}$ \\
\hline A. saligna & $540(650)$ & - & - & $\begin{array}{l}\text { Australia } \\
\text { (native range) }\end{array}$ & 6 & \\
\hline
\end{tabular}


Table 2 Continued.

\begin{tabular}{|c|c|c|c|c|c|c|}
\hline Acacia species & $\begin{array}{l}\text { Seed rain density } \\
\text { per } \mathrm{m}^{2} \text { per year (SRD) }\end{array}$ & $\begin{array}{l}\text { Seed bank density } \\
\text { per } \mathrm{m}^{2}(\mathrm{SBD})\end{array}$ & $\begin{array}{l}\text { Seed viability } \\
\text { (SV) }\end{array}$ & Region & References & Observations \\
\hline A. salicina & - & - & $77 \%$ & - & 22 & $\begin{array}{l}\text { SV - final germination } \\
\text { after scarification }\end{array}$ \\
\hline A. victoriae & - & $50-3900$ & $80 \%$ & $\begin{array}{l}\text { Australia } \\
\text { (native range) }\end{array}$ & 5 & \\
\hline
\end{tabular}

Values refer to mean values unless otherwise specified (standard deviation in parentheses where available).

1: Brown et al. (2003); 2: Burrows et al. (2009); 3: Cohen et al. (2008); 4: Fourie (2008); 5: Grice \& Westoby (1987); 6: C. Harris et al. (unpublished data); 7: Hellum (1990); 8: Holmes (1989); 9: Holmes (2002); 10: Holmes et al. (1987); 11: Jasson (2005); 12: Kulkarni et al. (2007); 13: H. Marchante, unpublished data; 14: Marchante et al. (2010); 15: Milton \& Hall (1981); 16: M. Morais, unpublished data; 17: Morgan (2003); 18: Morris (1997); 19: Pieterse (1987); 20: Pieterse (1997); 21: Pieterse \& Cairns (1986); 22: Rehman et al. (2000); 23: Saharjo \& Watanabe (2000); 24: Tozer (1998); 25: G. Valencia, unpublished data; 26: E.M. Wandrag, unpublished data; 27: Wood \& Morris (2007); 28: Zenni et al. (2009).

fire-driven ecosystems, other Acacia species originating from similar regions also likely possess such germination traits.

\section{Alternative modes of reproduction and persistence}

Acacia displays a variety of regeneration strategies besides germination from seed, including root suckering, and basal resprouting (Bell et al., 1993; Reid \& Murphy, 2008), which predispose them to weediness and can occur following disturbance such as fire and mechanical removal (Reid \& Murphy, 2006). In South Africa, for example, species such as A. cyclops, which lack the ability to resprout after fire, have high demographic dependence on seeds, while species such as A. saligna, which resprouts vigorously, depend less on seeds for population persistence. Spooner (2005) found that disturbance by road works in Australia triggered a range of responses, such as a combination of basal resprouting, root suckering and seedling emergence, which led to a population increase for three Acacia species. Similarly, resprouting is a major reproductive mechanism in A. dealbata in Chile and Europe and may facilitate its rapid invasion of new environments (Marchante et al., 2008; Lorenzo et al., 2010; Fuentes-Ramírez et al., 2011). Our study also found that resprout ability was greater for invasive species than for non-invasive species where they are introduced globally. Long-lived seed banks and ability to resprout are key determinants of persistence; together with the ability to disperse, these traits are hugely influential ingredients of invasive success since they ensure persistence and effectively permanent occupancy of invaded sites (e.g. Richardson \& Cowling, 1992).

\section{DISCUSSION}

Our literature review found that traits including generalist pollination systems, prolific seed production, efficient seed dispersal and the accumulation of large and persistent seed banks, which often have fire-, heat- or disturbance-triggered germination cues, are characteristic of Australian acacias in general. We did not find distinct reproductive syndromes that differed between invasive and non-invasive species, although this may be both because trait data were not available for all species, and those species for which data are available might not be representative.

Pollinator-mediated seed production is likely to facilitate invasion of Acacia species where they are introduced but should not differ for introduced non-invasive species as Australian acacias possess similar floral morphology and attract similar (generalist) pollinator groups (e.g. Apis mellifera). Flowering and seed production are clearly important for invasion success and account for the massive number of propagules that accumulate to create a long-lived soil seed bank that is the largest hurdle to effective control (Wilson et al., 2011). We found that invasive species reach reproductive maturity earlier, and this could certainly contribute to a faster accumulation of a seed bank, which is a vital requirement for ensuring persistence in regularly disturbed environments, such as those in which most Australian acacias are invasive (Richardson et al., 1990, p. 362). These results are supported in other studies that have also documented the important role of a short juvenile interval to seed production (in A. baileyana, see Morgan et al., 2002) and spread rate (in Pinus, see Higgins et al., 1996; Higgins \& Richardson, 1999). Time to reproductive maturity was also found to be shorter for invasive than non-invasive species when phylogeny was accounted for. This trait has not been discovered to have phylogenetic signal, and in an analysis using the most recent phylogeny for Australian Acacia, Miller et al. (2011) found that invasive species were phylogenetically over-dispersed (i.e. there was no phylogenetic signal for invasiveness). However, our results suggest that certain traits, which may be related to evolutionary history, can affect invasiveness and indicate that phenological precocity may be important for future consideration in phylogenetic studies.

Seed dispersal is critical for the spread of introduced Australian acacias, and although biotic dispersal agents are important, the majority of dispersal is likely human-mediated and focussed on economically important species. The ability to resprout undoubtedly aids in persistence during initial establishment as it makes a population less susceptible to stochastic events. This is supported by the results of our study that show 
resprout ability to be significantly greater for invasive species. Our results are similar to those of Pyšek \& Richardson (2007) who found that vegetative reproduction is positively associated with invasiveness in vascular plants across multiple comparative studies. However, resprouting ability should not directly aid in the ability of plants to spread.

There is much room to improve our knowledge of the reproductive biology in this genus. The role of pollinatormediated seed production, especially by Apis mellifera, appears to be important to reproductive success of Acacia where they are introduced, and this needs to be formally tested. In addition, self-compatibility has the potential to facilitate the invasion process by enabling seed production when mate and pollinator availability is low, but formal tests are needed to see whether effects of inbreeding depression cancel out such benefits. Whether the reproductive traits that we tested are related to evolutionary history is unknowable at this point. The lack of clear phylogenetic signal in Acacia is probably due to the lack of data both in the value of the reproductive traits and in the sampling of the phylogenetic tree. That our results suggest reproductive traits are related to evolutionary history is an important issue that will need further research. Thus, we recommend that future analyses incorporate variable and phylogenetic data for a wider array of invasive and noninvasive species (see Box 1 for a list of research priorities).

The finding that certain reproductive traits show no obvious correlation with invasiveness in Australian acacias may be attributable to a number of factors. First and foremost is the shortage of data for many Australian acacias, both invasive and non-invasive, and consequent small sample sizes (see Table 1A,B for sample sizes). This makes detection of more subtle correlations between reproductive traits and invasiveness difficult, resulting in an incomplete picture for understanding such relationships. Secondly, there is clearly no single 'ideal' reproductive syndrome that equips certain species in this group particularly well to establish, undergo rapid population growth (often from small founder populations), and to persist across the full range of habitats to which they have been introduced. Thirdly, if much of the reproductive trait data for invasive and non-invasive introduced species comes from studies within the native range, they may not incorporate differences in measurements because of region-specific factors of the introduced range. Such disparities in data highlight the need for measuring reproductive performance of individual invasive Acacia species in the introduced and native range. A fourth possibility is that all Australian acacias possess inherent reproductive and/or other life-history traits that facilitate invasiveness, and thus, all Australian acacias have the capacity to become invasive. Specific features of reproductive biology may be less important than a range of human-mediated factors that influence the abundance and distribution of species across potentially invasible sites, such as facets of the introduction history, propagule pressure, residence time and countryspecific utilization or treatment of particular species via economic, environmental and social avenues.

Key stages for invasiveness of the reproductive life cycle of Australian acacias are useful to identify to determine options for the intervention to reduce success and achieve management objectives (Wilson et al., 2011). Control efforts should aim, in the first instance, to prevent the accumulation of massive seed banks (Richardson \& Kluge, 2008) as once a seed bank is established, the population is practically impossible to eradicate. Biological control provides the most cost efficient, longterm control method and should be the foundation of effective integrated control operations. The upper seed bank is where the majority of Acacia seeds are able to successfully germinate and so should be the target area for control measures of which burning is the most effective. However, the applicability in practice of such useful additional measures as burning, mechanical control and herbicide application is context specific. To reduce human-mediated dispersal, planting Australian acacias near points of dispersal pathways (e.g. near

Box 1 Priorities for future research on the reproductive ecology of Australian acacias

\footnotetext{
To elucidate determinants of invasiveness, a variety of approaches are necessary to establish a complete profile for identifying reproductive traits consistently associated with invasion success in novel environments. This includes conducting multi-species studies encompassing native and multiple introduced ranges and comparative studies that contrast invasive Acacia species with co-occurring native species, as well as with non-invasive Acacia species or closely related taxa. Data for these comparisons regarding reproductive traits are widely lacking, and further studies are needed to gather information on reproductive biology.

Very little research has been carried out on the pollination biology of Australian acacias. Given its fundamental role in reproductive success and therefore invasion, further research is needed to determine the relative contributions of different insect visitors and wind pollination to outcrossing and seed set in the introduced range for invasive species and non-invasive species as well as for invasive species in exotic and native ranges. This information could be used to determine whether pollination efficiency contributes to a species' invasiveness.

Both breeding system data, based on controlled pollinations that indicate potential for selfing, and mating system data, based on molecular markers that give the rates of outcrossing, are needed. Breeding system data are lacking for some invasive Acacia species and for almost all noninvasive species in their introduced ranges. Comparisons are needed between both groups to determine how breeding system links to invasiveness and also between invasive species in the native range and in the introduced range to examine the extent of interspecific breeding system plasticity. Findings have implications for management protocols regarding genetic modifications and expected seed yields following self-pollination.

Thorough documentation of seed dispersal syndromes in the group is needed, for example, to determine whether the bird-dispersal syndrome is overrepresented in taxa that have become invasive. Insights from such work will provide useful information for improving the management of already invasive Australian acacias and help to refine tools for more effective screening of new introductions.
} 
rivers, along roads) should be prohibited (Wilson et al., 2011). Although the significant association of resprouting ability with invasiveness in the phylogeny-free analyses may be misleading in evolutionary terms, it is still useful from a management perspective. Thus, wherever Australian Acacia species that attain reproductive maturity early or have a strong capacity for resprouting are planted, proactive measures should be implemented to manage invasiveness.

Despite our attempts to test for individual reproductive traits that contribute to invasiveness, larger sample sizes facilitated by greater data availability are necessary before any firm conclusions can be drawn in this regard. Because there is still a depauperate knowledge surrounding this group of globally important invasive plants, reproductive traits of invasive Australian acacias and their distinguishing characteristics need to be the focus of future research directives (see Box 1). Hence, until there is substantial evidence to the contrary, caution should be exercised concerning introductions of all Australian acacias given their general ability to reproduce effectively in new locations.

\section{ACKNOWLEDGEMENTS}

We acknowledge financial support from the DST-NRF Centre of Excellence for Invasion Biology and the Working for Water programme through their collaborative project on 'Research for Integrated Management of Invasive Alien Species', Stellenbosch University and the Oppenheimer Memorial Trust. We thank Peter Bernhardt for providing information and references on Acacia pollination and Rod Griffin and Stephen Midgley for information on features that distinguish invasive from noninvasive Australian acacias. Graciela Valencia kindly shared information on $A$. dealbata in Chile and Haylee Kaplan on A. implexa and A. stricta in South Africa. Rod Griffin and Jane Habbard supplied information on ploidy and breeding systems. E. M. was supported by FCT-MCTES, grant SFRH/BPD/63211/ 2009 and H. M. by FCT-MCTES, grant SFRH/BD/24987/2005.

\section{REFERENCES}

Alves, E.M.S. \& Marins-Corder, M.P. (2009) Reproductive biology of Acacia mearnsii De Wild. (Fabaceae) IV: flower visitors. Revista Arvore, 33, 443-450.

Anderson, S.H., Kelly, D., Robertson, A.W., Ladley, J.J. \& Innes, J.G. (2006) Birds as pollinators and dispersers: a case study from New Zealand. Acta Zoologica Sinica, 52, 112-115.

Andrew, R.L., Miller, J.T., Peakall, R., Crisp, M.D. \& Bayer, R.J. (2003) Genetic, cytogenetic and morphological patterns in a mixed mulga population: evidence for apomixis. Australian Systematic Botany, 16, 69-80.

Baker, H.G. (1955) Self-compatibility and establishment after

'long-distance' dispersal. Evolution, 9, 347-368.

Barrett, S.C.H., Harder, L.D. \& Worley, A.C. (1996) The comparative biology of pollination and mating in flowering plants. Philosophical Transactions: Biological Sciences, 351, 1271-1280.
Barthell, J.F., Randall, J.M., Thorp, R.W. \& Wenner, A.M. (2001) Promotion of seed set in yellow star-thistle by honey bees: evidence of an invasive mutualism. Ecological Applications, 11, 1870-1883.

Bell, D.T., Plummer, J.A. \& Taylor, S.K. (1993) Seed germination ecology in southwestern Western Australia. Botanical Review, 59, 24-73.

Berg, R.Y. (1975) Myrmecochorous plants in Australia and their dispersal by ants. Australian Journal of Botany, 23, 475508.

Bernhardt, P. (1987) A comparison of the diversity, density, and foraging behavior of bees and wasps on Australian Acacia. Annals of the Missouri Botanical Garden, 74, 42-50.

Bernhardt, P. (1989) The floral biology of Australian Acacia. Advances in legume biology (ed. by C.H. Stirton and J.L. Zarucchi), pp. 263-281, Missouri Botanical Garden, St Louis, Missouri.

Bernhardt, P., Kenrick, J. \& Knox, R.B. (1984) Pollination biology and the breeding system of Acacia retinodes (Leguminosae: Mimosoideae). Annals of the Missouri Botanical Garden, 71, 17-29.

Broadhurst, L.M. \& Young, A.G. (2006) Reproductive constraints for the long-term persistence of fragmented Acacia dealbata (Mimosaceae) populations in southeast Australia. Biological Conservation, 133, 512-526.

Broadhurst, L.M., Young, A.G. \& Forrester, R. (2008) Genetic and demographic responses of fragmented Acacia dealbata (Mimosaceae) populations in southeastern Australia. Biological Conservation, 141, 2843-2856.

Brown, B.J., Mitchell, R.J. \& Graham, S.A. (2002) Competition for pollination between an invasive species (purple loosestrife) and a native congener. Ecology, 83, 2328-2336.

Brown, J., Enright, N.J. \& Miller, B.P. (2003) Seed production and germination in two rare and three common co-occurring Acacia species from south-east Australia. Austral Ecology, 28, 271-280.

Buist, M.L. (2003) Comparative ecology and conservation biology of two critically endangered acacias (Acacia lobulata and A. sciophanes) and two common, widespread relatives (Acacia verricula and A. anfractuosa) from the south-west of Western Australia. PhD thesis, The University of Western Australia.

Burrows, G.E., Virgona, J.M. \& Heady, R.D. (2009) Effect of boiling water, seed coat structure and provenance on the germination of Acacia melanoxylon seeds. Australian Journal of Botany, 57, 139-147.

Butcher, P.A., Glaubitz, J.C. \& Moran, G.F. (1999) Applications for microsatellite markers in the domestication and conservation of forest trees. Forest Genetic Resources Information, 27, 34-42.

Cadotte, M.W. \& Lovett-Doust, J. (2001) Ecological and taxonomic differences between native and introduced plants of southwestern Ontario. Ecoscience, 8, 230-238.

Castro-Díez, P., Godoy, O., Saldaña, A. \& Richardson, D.M. (2011) Predicting invasiveness of Australian acacias on the basis of their native climatic affinities, life-history traits and human use. Diversity and Distributions, 17, 934-945. 
Chittka, L. \& Schürkens, S. (2001) Successful invasion of a floral market. Nature, 411, 653.

Coates, D.J., Tischler, G. \& McComb, J.A. (2006) Genetic variation and the mating system in the rare Acacia sciophanes compared with its common sister species Acacia anfractuosa (Mimosaceae). Conservation Genetics, 7, 931-944.

Cohen, O., Riov, J., Katan, J., Gamliel, A. \& Bar, P. (2008) Reducing persistent seed banks of invasive plants by soil solarization- the case of Acacia saligna. Weed Science, 56, 860-865.

Costermans, L. (2007) Native trees and shrubs of south-eastern Australia, Reed New Holland, Sydney, Australia.

Davidson, D.W. \& Morton, S.R. (1984) Dispersal adaptations of some Acacia species in the Australian arid zone. Ecology, 65, 1038-1051.

Davis, H.G., Taylor, C.M., Lambrinos, J.G. \& Strong, D.R. (2004) Pollen limitation causes an Allee effect in a windpollinated invasive grass (Spartina alterniflora). Proceedings of the National Academy of Sciences USA, 101, 13804-13807.

Dennill, G.B. \& Donnelly, D. (1991) Biological control of Acacia longifolia and related weed species (Fabaceae) in South Africa. Agriculture, Ecosystems, and Environment, 37, 115-135.

Don, W. (2007) Ants of New Zealand. Otago University Press, Dunedin, New Zealand.

Duckworth, A. \& Richardson, D.M. (1988) Notes on the diet of helmeted guineafowl (203) in the Jonkershoek Valley, Stellenbosch. Promerops, 186, 11.

Eckert, C.G., Samis, K.E. \& Dart, S. (2006) Reproductive assurance and the evolution of uniparental reproduction in flowering plants. Ecology and evolution of flowers (ed. by L.D. Harder and S.C.H. Barrett), pp. 183-203. Oxford University Press, Oxford.

Farrell, T.P. \& Ashton, D.H. (1978) Population studies on Acacia melanoxylon R. Br. I. Variation in seed and vegetative characteristics. Australian Journal of Botany, 26, 365-379.

Fourie, S. (2008) Composition of the soil seed bank in alieninvaded grassy fynbos: potential for recovery after clearing. South African Journal of Botany, 74, 445-453.

Fraser, M.W. (1990) Foods of Redwinged Starlings and the potential for avian dispersal of Acacia cyclops at the Cape of Good Hope Nature Reserve. South African Journal of Ecology, 1, 73-76.

French, K. \& Major, R.A. (2001) Effect of an exotic Acacia (Fabaceae) on ant assemblages in South African fynbos. Austral Ecology, 26, 303-310.

Friedman, J. \& Barrett, S.C.H. (2009) Wind of change: new insights on the ecology and evolution of pollination and mating in wind-pollinated plants. Annals of Botany, 103, 1515-1527.

Fuentes-Ramírez, A., Pauchard, A., Cavieres, L.A. \& García, R.A. (2011) Survival and growth of Acacia dealbata vs. native trees across an invasion front in south-central Chile. Forest Ecology and Management, 261, 1003-1009.

Gallagher, R.V., Leishman, M.R., Miller, J.T., Hui, C., Richardson, D.M., Suda, J. \& Trávníček, P. (2011) Invasion success of introduced Australian acacias: the role of species' traits and genome size. Diversity and Distributions 17, 884897.

Gaol, M.L. \& Fox, J.E.D. (2002) Reproductive potential of Acacia species in the central wheatbelt: variation between years. Conservation Science Western Australia, 4, 147-157.

George, N., Byrne, M. \& Yan, G. (2008) Mixed mating with preferential outcrossing in Acacia saligna (Labill.) H. Wendl. (Leguminosae: Mimosoideae). Silvae Genetica, 57, 139-145.

George, N., Byrne, M. \& Yan, G. (2009) Observations of the reproductive biology of Acacia saligna (Labill.) H.L. Wendl. Journal of the Royal Society of Western Australia, 92, 5-14.

Ghazoul, J. (2002) Flowers at the front line of invasion? Ecological Entomology, 27, 638-640.

Gill, A.M. (1985) Acacia cyclops G. Don (LeguminosaeMimosaceae) in Australia: distribution and dispersal. Journal of the Royal Society of Western Australia, 67, 59-65.

Glyphis, J.P., Milton, S.J. \& Siegfried, W.R. (1981) Dispersal of Acacia cyclops by birds. Oecologia, 48, 138-141.

Godoy, O., Richardson, D.M., Valladares, F. \& Castro-Díez, P. (2009) Flowering phenology of invasive alien plant species compared with native species in three Mediterranean-type ecosystems. Annals of Botany, 103, 485-494.

Gordon, D.R., Riddle, B., Pheloung, P.C., Ansari, S., Buddenhagen, C., Chimera, C., Daehler, C.C., Dawson, W., Denslow, J.S., Tshidada, N.J., LaRosa, A., Nishida, T., Onderdonk, D.A., Panetta, F.D., Pyšek, P., Randall, R.P., Richardson, D.M., Virtue, J.G. \& Williams, P.A. (2010) Guidance for addressing the Australian Weed Risk Assessment questions. Plant Protection Quarterly, 25(2), 56-74.

Grice, A.C. \& Westoby, M. (1987) Aspects of the dynamics of the seed-banks and seedling populations of Acacia victoriae and Cassia spp. in arid western New South Wales. Australian Journal of Ecology, 12, 209-215.

Gross, C.L., Gorrell, L., Macdonald, M.J. \& Fatemi, M. (2010) Honeybees facilitate the invasion of Phyla canescens (Verbenaceae) in Australia - no bees, no seed! Weed Research, 50, 364-372.

Hadfield, J.D. \& Nakagawa, S. (2010) General quantitative genetic methods for comparative biology: phylogenies, taxonomies and multitrait models for continuous and categorical characters. Journal of Evolutionary Biology, 23, 494508.

Hall, T.A. (1999) BioEdit: a user-friendly biological sequence alignment editor and analysis program for Windows 95/98/ NT. Nucleic Acids Symposium Series, 41, 95-98.

Hamilton, M.A., Murray, B.R., Cadotte, M.W., Hose, G.C., Baker, A.C., Harris, C.J. \& Licari, D. (2005) Life-history correlates of plant invasiveness at regional and continental scales. Ecology Letters, 8, 1066-1074.

Harder, L.D. \& Johnson, S.D. (2008) Function and evolution of aggregated pollen in angiosperms. International Journal of Plant Sciences, 169, 59-78.

Hardner, C.M. \& Potts, B.M. (1997) Postdispersal selection following mixed mating in Eucalyptus regnans. Evolution, 51, 103-111. 
Hellum, A.K. (1990) Seed ecology in a population of Acacia holosericea. Canadian Journal of Forest Research, 20, 927933.

Henderson, L. (2001) Alien weeds and invasive plants: a complete guide to declared weeds and invaders in South Africa, Agricultural Research Council of South Africa, Pretoria, South Africa.

Herlihy, C.R. \& Eckert, C.G. (2002) Genetic cost of reproductive assurance in a self-fertilizing plant. Nature, 416, 320 323.

Higgins, S.I. \& Richardson, D.M. (1999) Predicting plant migration in a changing world: the role of long-distance dispersal. American Naturalist, 153, 464-475.

Higgins, S.I., Richardson, D.M. \& Cowling, R.M. (1996) The role of plant-environment interactions and model structure on the predicted rate and pattern of invasive plant spread. Ecology, 77, 2043-2054.

Higgins, S.I., Richardson, D.M. \& Cowling, R.M. (2001) Validation of a spatial simulation model of a spreading alien plant population. Journal of Applied Ecology, 38, 571584.

Holmes, P.M. (1989) Effects of different clearing treatments on the seed bank dynamics of an invasive Australian shrub, Acacia cyclops, in the southwestern Cape, South Africa. Forest Ecology and Management, 28, 33-46.

Holmes, P.M. (1990a) Dispersal and predation in alien Acacia. Oecologia, 83, 288-290.

Holmes, P.M. (1990b) Dispersal and predation of alien Acacia seeds: effects of season and invading stand density. South African Journal of Botany, 56, 428-434.

Holmes, P.M. (1990c) Vertical movement of soil-stored seed at a sand plain fynbos site. South African Journal of Ecology, 1, 8-11.

Holmes, P.M. (2002) Depth distribution and composition of seed-banks in alien-invaded and uninvaded fynbos vegetation. Austral Ecology, 27, 110-120.

Holmes, P.M., Macdonald, I.A.W. \& Juritz, J. (1987) Effects of clearing treatment on seed banks of the alien invasive shrubs Acacia saligna and Acacia cyclops in the southern and southwestern Cape, South Africa. Journal of Applied Ecology, 24, 1045-1051.

Impson, F.A.C., Moran, V.C. \& Hoffmann, J.H. (2004) Biological control of an alien tree, Acacia cyclops, in South Africa: impact and dispersal of a seed-feeding weevil, Melantarius servulus. Biological Control, 29, 375-381.

Ishida, K. (2006) Maintenance of inbreeding depression in a highly self-fertilizing tree, Magnolia obovata Thunb. Evolutionary Ecology, 20, 173-191.

Jasson, R. (2005) Management of Acacia species seed banks in the Table Mountain National Park, Cape Peninsula, South Africa, $\mathrm{PhD}$ thesis, Stellenbosch University, South Africa.

Kenrick, J. (2003) Review of pollen-pistil interactions and their relevance to the reproductive biology of Acacia. Australian Systematic Botany, 16, 119-130.

Kenrick, J. \& Knox, R.B. (1982) Function of the polyad in reproduction of Acacia. Annals of Botany, 50, 721-727.
Kenrick, J. \& Knox, R.B. (1989) Quantitative analysis of selfincompatibility in trees of seven species of Acacia. Journal of Heredity, 80, 240-245.

Kenrick, J., Bernhardt, P., Marginson, R., Beresford, G., Knox, R.B., Baker, I. \& Baker, H.G. (1987) Pollination-related characteristics in the mimosoid legume Acacia terminalis (Leguminosae). Plant Systematics and Evolution, 157, 49-62.

Kerala Agricultural University (2002) Package of Practices Recommendations: Crops. Kerala Agricultural University, Trichur.

Knight, R.S. \& Macdonald, I.A.W. (1991) Acacias and korhaans: an artificially assembled seed dispersal system. South African Journal of Botany, 57, 220-225.

Knox, R.B., Kenrick, J., Bernhardt, P., Marginson, R., Beresford, G., Baker, I. \& Baker, H.G. (1985) Extrafloral nectaries as adaptations for bird pollination in Acacia terminalis. American Journal of Botany, 72, 1185-1196.

Kulkarni, M.G., Sparg, S.G. \& Van Staden, J. (2007) Germination and post-germination response of Acacia seeds to smoke-water and butenolide, a smoke-derived compound. Journal of Arid Environments, 69, 177-187.

Kull, C.A. \& Rangan, H. (2008) Acacia exchanges: wattles, thorn trees, and the study of plant movements. Geoforum, 39, 1258-1272.

Langeland, K.A. \& Burks, K.C. (1998) Identification and biology of non-native plants in Florida's natural areas, IFAS Publication, University of Florida, Gainesville, Florida.

Le Roux, J.J., Brown, G., Byrne, M., Richardson, D.M. \& Wilson, J.R.U. (2011) Phylogeographic consequences of different introduction histories of invasive Australian Acacia species and Paraserianthes lophantha (Fabaceae) in South Africa. Diversity and Distributions, 17, 861-871.

Lorenzo, P., Gonzalez, L. \& Reigosa, M.J. (2010) The genus Acacia as invader: the characteristic case of Acacia dealbata Link in Europe. Annals of Forest Science, 67, 1-11.

Marchante, E., Freitas, H. \& Marchante, H. (2008) Guia Prático para a Identificação de Plantas invasoras de Portugal Continental [Invasive plant species in Portugal: guide for identification and control]. Imprensa da Universidade de Coimbra, Coimbra.

Marchante, H., Freitas, H. \& Hoffmann, J.H. (2010) Seed ecology of an invasive alien species, Acacia longifolia (Fabaceae), in Portuguese dune ecosystems. American Journal of Botany, 97, 1-11.

McNeill, J., Barrie, F.R., Burdet, H.M., Demoulin, V., Hawksworth, D.L., Marhold, K., Nicholson, D.H., Prado, J., Silva, P.C., Skog, J.E., Wiersema, J.H. \& Turland, N.J. (eds) (2006) International code of botanical nomenclature (Vienna Code): Adopted by the Seventeenth International Botanical Congress Vienna, Austria, July 2005. Regnum Vegetabile 146. Gantner, Ruggell.

Middlemiss, E. (1963) The distribution of Acacia cyclops in the Cape Peninsula area by birds and other animals. South African Journal of Science, 59, 419-420.

Millar, M.A., Byrne, M., Nuberg, I. \& Sedgley, M. (2008) High outcrossing and random pollen dispersal in a planted stand 
of Acacia saligna subsp. saligna revealed by paternity analysis using microsatellites. Tree Genetics and Genomes, 4, 367-377.

Millar, M.A., Byrne, M., Nuberg, I. \& Sedgley, M. (2011) High levels of genetic contamination in remnant populations of Acacia saligna from a genetically divergent planted stand. Restoration Ecology, 19.

Miller, J.T., Murphy, D.J., Brown, G.K., Richardson, D.M. \& González-Orozco, C.E. (2011) The evolution and phylogenetic placement of invasive Australian Acacia species. Diversity and Distributions, 17, 848-860.

Milton, S.J. \& Hall, A.V. (1981) Reproductive biology of Australian acacias in the south-western Cape Province, South Africa. Transactions of the Royal Society of South Africa, 44, 465-485.

Moffett, A.A. (1956) Genetical studies in acacias. 1. The estimation of natural crossing in Black Wattle. Heredity, 10, 57-67.

Moffett, A.A. \& Nixon, K.M. (1974) The effects of self-fertilization on green wattle (Acacia decurrens Willd.) and black wattle (Acacia mearnsii De Wild.). South Africa Wattle Institute Report, 1973-1974, 66-84.

Moncur, M.W., Moran, G.F., Boland, D.J. \& Turner, J. (1989) Floral morphology and breeding systems of Acacia mearnsii De Wild. Proceedings of the Uses of Australian Trees in China, Guangzhou.

Moncur, M.W., Moran, G.F. \& Grant, J.E. (1991) Factors limiting seed production in Acacia mearnsii. Advances in tropical acacia research (ed. by J.W. Turnbull), pp. 20-25. Australian Centre for International Agricultural Research, Canberra.

Morales, C.L. \& Aizen, M.A. (2002) Does invasion of exotic plants promote invasion of exotic flower visitors? A case study from the temperate forests of the southern Andes. Biological Invasions, 4, 87-100.

Moran, G.F., Muona, O. \& Bell, J.C. (1989a) Acacia mangium: a tropical forest tree of the coastal lowlands with low genetic diversity. Evolution, 43, 231-235.

Moran, G.F., Muona, O. \& Bell, J.C. (1989b) Breeding systems and genetic diversity in Acacia auriculiformis and Acacia crassicarpa. Biotropica, 21, 250-256.

Moravcová, L., Pyšek, P., Jarošík, V., Havlíčková, V. \& Zákravský, P. (2010) Reproductive characteristics of neophytes in the Czech Republic: traits of invasive and non-invasive species. Preslia, 82, 365-390.

Morgan, A. (2003) Ornamental and weed potential of Acacia baileyana F. Muell: investigations of fertility and leaf colour. $\mathrm{PhD}$ thesis, University of Adelaide, Adelaide, Australia.

Morgan, A., Carthew, S.M. \& Sedgley, M. (2002) Breeding system, reproductive efficiency and weed potential of Acacia baileyana. Australian Journal of Botany, 50, 357-364.

Morris, M.J. (1997) Impact of the gall-forming rust fungus Uromycladium tepperianum on the invasive tree Acacia saligna in South Africa. Biological Control, 10, 75-82.

Muona, O., Moran, G.F. \& Bell, J.C. (1991) Hierarchical patterns of correlated mating in Acacia melanoxylon. Genetics, 127, 619-626.

New, T.R. (1984) A biology of acacias. Oxford University Press, Melbourne.
Niklas, K.J. (1985) The aerodynamics of wind pollination. Botanical Review, 51, 328-386.

Niklas, K.J. (1987) Pollen capture and wind-induced movement of compact and diffuse grass panicles - implications for pollination efficiency. American Journal of Botany, 74, 74-89.

O'Dowd, D.J. \& Gill, A.M. (1986) Seed dispersal syndromes of Australian Acacia. Seed dispersal (ed. by D. Murray), pp. 87121, Academic Press, New York.

Parker, M.A., Malek, W. \& Parker, I.M. (2006) Growth of an invasive legume is symbiont limited in newly occupied habitats. Diversity and Distributions, 12, 563-571.

Pauchard, A., Maheu-Giroux, M., Aguayo, M. \& Esquivel, J. (2008) COS 10-1: Detecting invasion processes at the landscape and regional scales: Acacia dealbata in Chile. 93rd Ecological Society of America Annual Meeting, Milwaukee, Wisconsin.

Philp, J. \& Sherry, S.P. (1946) The degree of natural crossing in green wattle, Acacia decurrens Willd. and its bearing on wattle breeding. Journal of the South African Forestry Association, 14, 1-28.

Pieterse, P.J. (1987) Acacia longifolia and its control: to burn or not to burn? Veld and Flora, 73, 67-68.

Pieterse, P.J. (1997) Biological studies on woody leguminous invaders with special reference to Acacia mearnsii, Acacia melanoxylon and Paraserianthes lophantha. $\mathrm{PhD}$ thesis, Stellenbosch University, South Africa.

Pieterse, P.J. \& Cairns, A.L.P. (1986) The effect of fire on an Acacia longifolia seed bank in the south-western Cape. South African Journal of Botany, 52, 233-236.

Pinheiro, J., Bates, D., DebRoy, S. \& Sarkar, D.\& the R Core team, (2009) nlme: Linear and Nonlinear Mixed Effects Models. R package version 3.1-96.

Posada, D. \& Crandall, K.A. (1998) MODELTEST: testing the model of DNA substitution. Bioinformatics, 14, 817-818.

Prescott, M.N. (2005) The pollination ecology of a south-eastern Australia Acacia community. Unpublished $\mathrm{PhD}$ thesis, Oxford University.

Pyšek, P. \& Richardson, D.M. (2007) Traits associated with invasiveness in alien plants: where do we stand? Biological invasions (ed. by W. Nentwig), pp. 97-125. Springer, Berlin.

Pyšek, P., Richardson, D.M., Rejmánek, M., Webster, G.L., Williamson, M. \& Kirschner, J. (2004) Alien plants in checklists and floras: towards better communication between taxonomists and ecologists. Taxon, 53, 131-143.

Pyšek, P., Richardson, D.M., Pergl, J., Jarošík, V., Sixtova, Z. \& Weber, E. (2008) Geographical and taxonomic biases in invasion ecology. Trends in Ecology and Evolution, 23, 237-244.

Pyšek, P., Jarošík, V., Pergl, J., Randall, R., Chytrý, M., Kühn, I., Tichý, L., Danihelka, J., Chrtek, J.jun. \& Sádlo, J. (2009) The global invasion success of Central European plants is related to distribution characteristics in their native range and species traits. Diversity and Distributions, 15, 891-903. Pyšek, P., Jarošík, V., Chytrý, M., Danihelka, J., Kühn, I., Pergl, J., Tichý, L., Biesmeijer, J., Ellis, W.N., Kunin, W.E. \& Settele, J. (2011) Successful invaders co-opt pollinators of native flora and accumulate insect pollinators with increasing residence time. Ecological Monographs, 81, 277-293. 
R Development Core Team (2011) R: A language and environment for statistical computing. $R$ Foundation for Statistical Computing, Vienna, Austria. ISBN 3-900051-07-0. http://www.R-project.org/.

Radford, I.J., Nicholas, M., Tiver, F., Brown, J. \& Kriticos, D. (2002) Seedling establishment, mortality, tree growth rates and vigour of Acacia nilotica in different Astrebla grassland habitats: implications for invasion. Austral Ecology, 27, 258268.

Raine, N.E., Sharp Pierson, A. \& Stone, G.N. (2007) Plantpollinator interactions in a Mexican Acacia community. Arthropod-Plant Interactions, 1, 101-117.

Rambuda, T.D. \& Johnson, S.D. (2004) Breeding systems of invasive alien plants in South Africa: does Baker's rule apply? Diversity and Distributions, 10, 409-416.

Randall, R.P. (2002) A global compendium of weeds, R.G. \& F.J. Richardson, Meredith, Victoria, Australia.

Rehman, S., Harris, P.J.C., Bourne, W.F. \& Wilkin, J. (2000) The relationship between ions, vigour and salinity tolerance of Acacia seeds. Plant and Soil, 220, 229-233.

Reid, J.C. \& Murphy, D.J. (2006) Wattles as weeds: some case studies from western Victoria, National Herbarium of Victoria, Royal Botanic Gardens, Melbourne.

Reid, J.C. \& Murphy, D.J. (2008) Some case studies of acacias as weeds and implications for herbaria. Muelleria, 26, 57-66.

Rejmánek, M., Richardson, D.M., Higgins, S.I., Pitcairn, M.J. \& Grotkopp, E. (2005) Ecology of invasive plants: state of the art. Invasive alien species: searching for solutions (ed. by H.A. Mooney, R.M. Mack, J.A. McNeely, L. Neville, P. Schei and J. Waage), pp. 104-161, Island Press, Washington, DC.

Richardson, D.M. (2006) Pinus: a model group for unlocking the secrets of alien plant invasions? Preslia, 78, 375-388.

Richardson, D.M. \& Cowling, R.M. (1992) Why is mountain fynbos invasible and which species invade? Fire in South African mountain fynbos (ed. by B.W. van Wilgen, D.M. Richardson, F.J. Kruger and H.J. van Hensbergen), pp. 161181, Springer-Verlag, Berlin.

Richardson, D.M. \& Kluge, R.L. (2008) Seed banks of invasive Australian Acacia species in South Africa: role in invasiveness and options for management. Perspectives in Plant Ecology Evolution and Systematics, 10, 161-177.

Richardson, D.M. \& Pyšek, P. (2006) Plant invasions: merging the concepts of species invasiveness and community invasibility. Progress in Physical Geography, 30, 409-431.

Richardson, D.M. \& Rejmánek, M. (2011) Trees and shrubs as invasive alien species - a global review. Diversity and Distributions, 17, 788-809.

Richardson, D.M., Cowling, R.M. \& Le Maitre, D.C. (1990) Assessing the risk of invasive success in Pinus and Banksia in South African mountain fynbos. Journal of Vegetation Science, 1, 629-642.

Richardson, D.M., Allsopp, N., D’Antonio, C.M., Milton, S.J. \& Rejmánek, M. (2000a) Plant invasions - the role of mutualisms. Biological Reviews, 75, 65-93.

Richardson, D.M., Pyšek, P., Rejmánek, M., Barbour, M.G., Panetta, F.D. \& West, C.J. (2000b) Naturalization and invasion of alien plants: concepts and definitions. Diversity and Distributions, 6, 93-107.

Richardson, D.M., Carruthers, J., Hui, C., Impson, F.A.C., Robertson, M.P., Rouget, M., Le Roux, J.J. \& Wilson, J.R.U. (2011) Human-mediated introductions of Australian acacias - a global experiment in biogeography. Diversity and Distributions, 17, 771-787.

Ridley, H.N. \& Moss, M.B. (1930) The dispersal of plants throughout the world. Reeve, Ashford.

Robertson, A.W., Kelly, D. \& Ladley, J.J. (2011) Futile selfing in the trees Fuchsia excorticata (Onagraceae) and Sophora microphylla (Fabaceae): inbreeding depression over 11 years. International Journal of Plant Sciences, 172, 191198.

Rodríguez-Echeverría, S., Le Roux, J.J., Crisóstomo, J.A. \& Ndlovu, J. (2011) Jack of all trades and master of many? How does associated rhizobial diversity influence the colonization success of Australian Acacia species? Diversity and Distributions, 17, 946-957.

Ronquist, F. \& Huelsenbeck, J.P. (2003) MrBayes 3: bayesian phylogenetic inference under mixed models. Bioinformatics, 19, 1572-1574.

Saharjo, B.H. \& Watanabe, H. (2000) Estimation of litter fall and seed production of Acacia mangium in a forest plantation in South Sumatra, Indonesia. Forest Ecology and Management, 130, 265-268.

Sedgley, M. (1985) Some effects of temperature and light on floral initiation and development in Acacia pycnantha. Australian Journal of Plant Physiology, 12, 109-118.

Sedgley, M., Harbard, J., Smith, R.-M.M., Wickneswari, R. \& Griffin, A.R. (1992) Reproductive biology and interspecific hybridization of Acacia mangium and Acacia auriculiformis A. Cunn. ex Benth. (Leguminosae: Mimosoideae). Australian Journal of Botany, 40, 37-48.

Sornsathapornkul, P. \& Owens, J.N. (1998) Pollination biology in a tropical Acacia hybrid (A. mangium Willd. x A. auriculiformis A. Cunn. ex Benth.). Annals of Botany, 81, 631-645. Specht, R.L. \& Specht, A. (1999) Australian plant communities: dynamics of structure, growth, and biodiversity. Oxford University Press, Oxford.

Spooner, P.G. (2005) Response of Acacia species to disturbance by roadworks in roadside environments in southern New South Wales, Australia. Biological Conservation, 122, 231242.

Stanley, M.C. \& Lill, A. (2002) Avian fruit consumption and seed dispersal in a temperate Australian woodland. Austral Ecology, 27, 137-148.

Starr, F., Starr, K. \& Loope, L. (2003) Acacia mangium. http:// www.hear.org/Pier/pdf/pohreports/acacia_mangium.pdf. (Accessed on 27 November 2010).

Stone, G.N., Willmer, P. \& Rowe, J.A. (1998) Partitioning of pollinators during flowering in an African Acacia community. Ecology, 79, 2808-2827.

Stone, G.N., Raine, N.E., Prescott, M. \& Willmer, P.G. (2003) Pollination ecology of acacias (Fabaceae, Mimosoideae). Australian Systematic Botany, 16, 103-118. 
Stone, G.N., Nee, S. \& Felsenstein, J. (2011) Controlling for non-independence in comparative analysis of patterns across populations within species. Philosophical Transactions of the Royal Society of London, Series B, 366, 14101424.

Thorp, R.W. \& Sugden, E.A. (1990) Extrafloral nectaries producing rewards for pollinator attraction in Acacia longifolia (Andr) Willd. Israel Journal of Botany, 39, 177-186.

Thuiller, W., Richardson, D.M., Rouget, M., Procheş, S. \& Wilson, J.R. (2006) Interactions between environment, species traits, and human use describe patterns of plant invasions. Ecology, 87, 1755-1769.

Tozer, M.G. (1998) Distribution of the soil seedbank and influence of fire on seedling emergence in Acacia saligna growing on the central coast of New South Wales. Australian Journal of Botany, 46, 743-756.

Trakhtenbrot, A., Nathan, R., Perry, G. \& Richardson, D.M. (2005) The importance of long-distance dispersal in biodiversity conservation. Diversity and Distributions, 11, 173181.

Underhill, L.G. \& Hofmeyr, J.H. (2007) Barn Swallows Hirundo rustica disperse seeds of Rooikrans Acacia cyclops, an invasive alien plant in the Fynbos Biome. Ibis, 149, 468-471.

Vanstone, V.A. \& Paton, D.C. (1988) Extrafloral nectaries and pollination of Acacia pycnantha Benth. by birds. Australian Journal of Botany, 36, 519-531.

Willmer, P.G. \& Stone, G.N. (2004) Behavioral, ecological, and physiological determinants of the activity patterns of bees. Advances in the Study of Behavior, 34, 347-466.

Wilson, J.R.U., Gairifo, C., Gibson, M.R. et al. (2011) Risk assessment, eradication, and biological control: global efforts to limit Australian acacia invasions. Diversity and Distributions, 17, 1030-1046.

de Wit, M.P., Crookes, D.J. \& van Wilgen, B.W. (2001) Conflicts of interest in environmental management: estimating the costs and benefits of a tree invasion. Biological Invasions, 3, 167-178.

Wood, A.R. \& Morris, M.J. (2007) Impact of the gall-forming rust fungus Uromycladium tepperianum on the invasive tree Acacia saligna in South Africa: 15 years of monitoring. Biological Control, 41, 68-77.

Wattle Research Institute (1952) Annual report of the Wattle Research Institute for 1951-1952 (fourth-fifth years). University of Natal, Pietermaritzburg.

Wattle Research Institute (1961) Annual report of the Wattle Research Institute for 1960-1961 (fourth-fifth years). University of Natal, Pietermaritzburg.

Yates, C.J. \& Broadhurst, L.M. (2002) Assessing limitations on population growth in two critically endangered Acacia taxa. Biological Conservation, 108, 13-26.

Zenni, R.D., Wilson, J.R.U., Le Roux, J.J. \& Richardson, D.M. (2009) Evaluating the invasiveness of Acacia paradoxa in South Africa. South African Journal of Botany, 75, 485496.

\section{SUPPORTING INFORMATION}

Additional Supporting Information may be found in the online version of this article:

Table S1 The complete set of reproductive traits for introduced Australian acacias $(n=126)$.

Table S2 The complete set of reproductive traits for nonintroduced Australian acacias $(n=324)$.

Table S3 List of Australian Acacia flower visitors.

Appendix S1 Accession numbers for those species used in phylogenetic analyses.

Appendix S2 Phylogeny-free analyses of relationships between individual reproductive traits in Australian Acacia species and invasive status (invasive versus non-invasive).

Appendix S3 The effect of individual reproductive traits on Australian Acacia species' invasive status (invasive versus noninvasive) using phylogeny as a covariate.

As a service to our authors and readers, this journal provides supporting information supplied by the authors. Such materials are peer-reviewed and may be re-organized for online delivery, but are not copy-edited or typeset. Technical support issues arising from supporting information (other than missing files) should be addressed to the authors.

\section{BIOSKETCH}

All co-authors are actively involved in research on the ecology of Australian Acacia species. M. G. is a Master's student and S.D.J., J.J.L.R., D.M.R and J.R.U.W are core team members at the DST-NRF Centre of Excellence for Invasion Biology (http://academic.sun.ac.za/cib/). M.G.'s thesis at Stellenbosch University deals with the effects of Acacia saligna on native plant-pollinator communities. Her research interests lie in invasion biology, novel ecosystem interactions and restoration and conservation research.

Author contributions: M.R.G. and D.M.R. conceived the ideas; M.R.G., E.M. and H.M. collected most of the new data; M.B., N.G., M.R.G., C.H., E.M., H.M., J.T.M., D.J.M., M.N.P., J.G.R. and E.M.W. contributed additional data; J.J.L.R, J.T.M. and G.N.S. wrote the phylogenetic methods section; J.J.L.R. and J.T.M. reconstructed the phylogeny; M.R.G. and J.R.U.W. analysed the data; E.M. and H.M. created Table 2; J.G.R. and G.N.S. contributed to the 'Pollination biology' section; M.B., S.D.J. and J.G.R. contributed to the 'Breeding system' section; A.F.-R. contributed to 'Germination' section; A.P. provided conceptual insight and revision support. M.R.G. led the writing with support from D.M.R.

Editor: Petr Pyšek 


\section{APPENDIX 1}

Description of variables, abbreviations and levels used in statistical analyses and Table S1. T = True, $\mathrm{F}=$ False, NA $=$ not applicable.

\begin{tabular}{|c|c|c|c|c|}
\hline Variable type & Abbreviation & $\begin{array}{l}\text { No. species for } \\
\text { which data are } \\
\text { available }\end{array}$ & $\begin{array}{l}\text { Levels (and range of values if } \\
\text { continuous) }\end{array}$ & References \\
\hline \multicolumn{5}{|l|}{ Explanatory } \\
\hline \multicolumn{5}{|l|}{ Reproductive trait } \\
\hline $\begin{array}{l}\text { Age to reproductive } \\
\text { maturity }\end{array}$ & Mature & 39 & $\begin{array}{l}\text { Categorical, binary: } \\
\text { ' } 1 \text { ' } \leq 2 \text { years; ' } 2 \text { ' } \geq 2 \text { years }\end{array}$ & $1-6$ \\
\hline $\begin{array}{l}\text { Multi-locus outcrossing } \\
\text { rate }\left(t_{\mathrm{m}}\right)\end{array}$ & Outcross & 8 & Continuous: $0.65-0.97$ & $7-15$ \\
\hline $\begin{array}{l}\text { Index of self-incompatibility } \\
\text { (ISI) (infructescence per } \\
\text { inflorescence) }\end{array}$ & Compatible1 & 9 & Continuous: $0.02-0.96$ & $16-19$ \\
\hline ISI (pods per inflorescence) & Compatible2 & 10 & Continuous: $0.008-1.1$ & $16 ; 17 ; 19 ; 20$ \\
\hline Breeding system* & Breed & 13 & $\begin{array}{l}\text { Categorical: 'apomictic'; } \\
\text { 'SI' = self-incompatible; } \\
\text { 'pSC' = partially } \\
\text { self-compatible; } \\
\text { 'SC' = self-compatible }\end{array}$ & $9 ; 12 ; 16 ; 17 ; 19-22$ \\
\hline $\begin{array}{l}\text { Combined measure of } \\
\text { breeding system } \dagger\end{array}$ & Combined & 13 & $\begin{array}{l}\text { Categorical, binary: 'Mixed' or } \\
\text { 'Outcross' }\end{array}$ & see footnote $\dagger$ \\
\hline Seed dispersed by ants & Ant & 16 & Categorical: T/NA $\ddagger$ & $5 ; 20 ; 23-25 ; 26$ \\
\hline Seed dispersed by birds & Bird & 13 & Categorical: $\mathrm{T} / \mathrm{NA}$ & $6 ; 23 ; 24 ; 26-30$ \\
\hline Biotic seed dispersal & $\begin{array}{l}\text { Dispers (combination } \\
\text { of previous two } \\
\text { columns in Table S1) }\end{array}$ & 27 & $\begin{array}{l}\text { Categorical, binary: 'not bird' } \\
\text { dispersed if ant }=\mathrm{T} \& \\
\text { bird }=\mathrm{NA} \text {; 'bird' dispersed if } \\
\text { bird }=\mathrm{T}\end{array}$ & \\
\hline Seed mass & Seed mass & 122 & Continuous: $2.72-219.77$ (mg) & $1 ; 24 ; 31$ \\
\hline Resprout ability & Resprout & 75 & Categorical, binary: $\mathrm{T} / \mathrm{F}$ & $5 ; 31 ; 32$ \\
\hline Duration of flowering season & Flower duration & 81 & Continuous: $2-12$ (months) & $5 ; 31-33$ \\
\hline \multicolumn{5}{|l|}{ Response } \\
\hline Invasive or not invasive & Invasive & & Binary: $0 / 1$ & 34 \\
\hline
\end{tabular}

1: J.T. Miller, unpublished data; 2: Australian Native Plants Society, http://anpsa.org.au/a-pod.html, October 2010; 3: Global Invasive Species Database, http://interface.creative.auckland.ac.nz/database/species/ecology.asp?si=1662\&fr=1\&sts=sss\&lang=EN, 1 October 2010; 4: Kerala Agricultural University, 2002; 5: World Wide Wattle, http://www.worldwidewattle.com, February 2011; 6: Zenni et al. (2009); 7: Broadhurst et al. (2008); 8: Butcher et al. (1999); 9: George et al. (2008); 10: Millar et al. (2008); 11: Moffett (1956); 12: Moran et al. (1989b); 13: Muona et al. (1991); 14: Philp \& Sherry (1946); 15: Coates et al. (2006); 16: M. R. Gibson, unpublished data; 17: Kenrick \& Knox (1989); 18: Moncur et al. (1991); 19: J. G. Rodger, unpublished data; 20: Morgan et al. (2002); 21: Andrew et al. (2003); 22: Moffett \& Nixon (1974); 23: Davidson \& Morton (1984); 24: Kew Gardens Seed Information Database, http://data.kew.org/sid/sidsearch.html, February 2011; 25: Lorenzo et al. (2010); 26: O’Dowd \& Gill (1986); 27: Langeland \& Burks (1998); 28: Moran et al. (1989a); 29: Stanley \& Lill (2002); 30: Starr et al. (2003); 31: Castro-Díez et al. (2011); 32: D. J. Murphy, unpublished data; 33: Arbres et arbustes de La Réunion, http://arbres-reunion.cirad.fr/especes/fabaceae/acacia_heterophylla_willd, February 2011; 34: Richardson \& Rejmánek (2011).

${ }^{*}$ When only $t_{\mathrm{m}}$ was available, we used the criteria: SI is $t_{\mathrm{m}} \geq 0.8$.

$\dagger$ Inference from $t_{\mathrm{m}}$, ISI and breeding system for which species are classified as either outcrossing (if $t_{\mathrm{m}} \geq 0.8$ or ISI $\leq 0.5$ a species is classified as outcrossing) and otherwise as mixed mating.

$\$$ References could only confirm (and not refute) that an ant or bird dispersed seed of a given species, and thus, criteria for 'not bird' dispersed were required (see Biotic seed dispersal (above) and Methods section of main article). 